\title{
Genomic Medicine: Lessons Learned From Monogenic and Complex Bone Disorders
}

\author{
Katerina Trajanoska ${ }^{\dagger}$ and Fernando Rivadeneira ${ }^{*+}$ \\ Department of Internal Medicine, Erasmus MC University Medical Center, Rotterdam, Netherlands
}

OPEN ACCESS

Edited by:

Wim Van Hul,

University of Antwerp, Belgium

Reviewed by:

Sudip Sen,

All India Institute of Medical

Sciences, India

Cristina Sobacchi,

National Research Counci

(CNR), Italy

*Correspondence:

Fernando Rivadeneira

f.rivadeneira@erasmusmc.nl

tORCID:

Katerina Trajanoska orcid.org/0000-0002-3792-4296

Fernando Rivadeneira orcid.org/0000-0001-9435-9441

Specialty section:

This article was submitted to

Bone Research,

a section of the journal

Frontiers in Endocrinology

Received: 28 April 2020

Accepted: 21 August 2020

Published: 09 October 2020

Citation:

Trajanoska K and Rivadeneira F (2020) Genomic Medicine: Lessons Learned From Monogenic and Complex Bone

Disorders.

Front. Endocrinol. 11:556610.

doi: $10.3389 /$ fendo.2020.556610
Current genetic studies of monogenic and complex bone diseases have broadened our understanding of disease pathophysiology, highlighting the need for medical interventions and treatments tailored to the characteristics of patients. As genomic research progresses, novel insights into the molecular mechanisms are starting to provide support to clinical decision-making; now offering ample opportunities for disease screening, diagnosis, prognosis and treatment. Drug targets holding mechanisms with genetic support are more likely to be successful. Therefore, implementing genetic information to the drug development process and a molecular redefinition of skeletal disease can help overcoming current shortcomings in pharmaceutical research, including failed attempts and appalling costs. This review summarizes the achievements of genetic studies in the bone field and their application to clinical care, illustrating the imminent advent of the genomic medicine era.

Keywords: genomic medicine, osteoporosis, complex diseases, monogenic bone disorders, drug repurposing, Mendelian randomization

\section{INTRODUCTION}

The concept of "precision" or "personalized" medicine, i.e., individualized prevention and treatment tailored to a patient's individual needs is not new. What is clear is that it has gained notorious popularity over the past decade, fuelled by the advances in human genomics, setting the ground for the field of "Genomic Medicine." The biggest breakthroughs in the field were achieved with the emergence of the genome-wide screens across large study populations which have uncovered many novel molecular mechanisms underlying rare and common human diseases. This review summarizes the achievements of genetic studies in the bone field (both for monogenic and complex traits) and their application to clinical care, illustrating the imminent advent of the genomic medicine era.

The translation of genomic findings to the clinic has been particularly successful for the diagnostic screening and treatment of rare monogenic diseases. For instance, ivacaftor is a drug widely used in clinical practice to treat patients with cystic fibrosis; the compound targets directly the gene defect in patients with at least one G551D mutation in the CFTR gene (1). Gene therapy has also been introduced for several other monogenic diseases such as inherited immune deficiencies (2), hereditary blindness (3), hemophilia (4), and beta-thalassemia (5) among others. Similarly, tremendous progress has been made in cancer research with the development of the chimeric antigen receptor T cell (CAR-T) immunotherapy which acts as a "living drug" against cancer cells (6). In contrast, the translation of genomic discoveries for common diseases has lagged behind due to their complex nature, i.e., involvement of numerous genetic variants of weak effects and large environmental influence. 


\section{WHAT HAVE WE LEARNED FROM MONOGENIC SKELETAL DISORDERS?}

In general, monogenic diseases arise due to mutation in a specific gene and are responsible for sometimes life-threatening abnormalities across different bodily systems, including the musculoskeletal. Based on the inheritance pattern, monogenic diseases can be classified as recessive or dominant. These diseases have been extensively described in previous reviews (7-10). Below we will focus mainly on those musculoskeletal conditions where novel treatments have been developed.

\section{Osteogenesis Imperfecta}

Osteogenesis imperfecta (OI) is a group of genetic disorders characterized by weak bones, of which most are of autosomal dominant inheritance (types I, II, III, IV, V, and VI); while a few are inherited in an autosomal recessive manner (types VII, VIII and some cases of type III). Most of the mutations are present in either the COL1A1 or COL1A2 genes, which encode pro $\alpha 1$ (I) and pro $\alpha 2$ (I) collagen chains (11). Mutations in these genes affect the composition of the bone matrix and bone architecture, due to alterations in the collagen cross-links and of collagen 1 triple helix formation. These material properties of collagen 1 fibrils constitute strong determinants of bone strength, and are affected to varying degrees in OI (type I-IV). Notably, the COL1A1 gene has also been associated with variation in bone mineral density (BMD) in the general population (12).

Patients with OI display wide range of skeletal features such as low bone mass, increased bone fragility and fracture risk, physical disability, and chronic pain which altogether decrease the quality of life. OI treatment is based on disease severity and patient's specific symptoms. While still pending to reach clinical application, several efforts have been made to correct the underlying genetic defect of OI. Chamberlain et al. using adeno-associated virus (AAV) targeting vector have successfully inactivated mutant COL1A1 (13) and COL1A2 (14) genes in OI mesenchymal stem cells (MSCs), thus restoring the production of normal type 1 procollagen. Induced pluripotent stem cells (iPSCs) generated from gene-targeted MSCs isolated from OI patients were able to differentiate to osteoblasts and produce normal collagen as well (15). Recently, using CRISPRCas9 several iPSC lines have been created to explore the OI mechanisms and therapeutic approaches in vivo $(16,17)$. Furthermore, MSC transplantation in OI patients has showed promising results leading to increased BMD and decreased fracture risk after transplantation in both mice and humans (1821). In 2016, EU approved the Boost Brittle Bones Before Birth (BOOSTB4) study whose sole aim is to perform Phase I/II clinical trials on the safety and efficacy of prenatal and/or postnatal transplantation of fetal-derived MSC for severe forms of OI (Type III and IV) (22). Finally, it has been also shown that allelespecific Colla1 and Colla2 silencing using small interfering RNAs leads to reduction of the mutant collagen in both human and mice cell models $(23,24)$. These findings should be further replicated and validated before moving into clinic.

Overall, all of these approaches have shown to have possible therapeutic benefit in OI types I-IV. Much less is known about the other forms of OI (types V-XVII) caused by mutations in other genes: IFITM5 (type V), SERPINF1 (type VI), CRTAP (type VII); LEPRE1 (type VIII), PPIB (type IX), SERPINH1 (type X), FKBP10 (type XI), SP7 (type XII), BMP1 (type XIII), TMEM38B (type XIV), WNT1 (type XV), and SPARC (type XVII).

\section{Osteopetrosis}

Osteopetrosis is a group of rare bone disorders characterized by high bone mass due to defects in osteoclast differentiation and function. The abnormal bone remodeling leads to a variety of skeletal and dental deformities. Moreover, severe forms of osteopetrosis can expand to the bone marrow and the cranial nerve foramina resulting in a plethora of hematological and neurological complications (9). The autosomal dominant form of osteopetrosis (ADO), i.e., Albers-Schönberg disease, is caused primarily by heterozygous mutations in the chloride channel 7 (CLCN7) gene (25). On the other hand, there are eight different forms of autosomal recessive osteopetrosis (ARO) [reviewed elsewhere (26)] caused by mutations across several different genes such as TCIRG1, CAII, OSTM1, TNFSF11, TNFRSF11A among others.

The clinical diagnosis of osteopetrosis can be easily made using simple X-ray. Nevertheless, it is important to distinguish between the different forms of osteopetrosis using genetic testing as this will determine the choice of disease treatment and prognosis. For instance, patients with CAII deficiency are at high risk of developing nephrocalcinosis and nephrolithiasis (27), whereas patients with mutations in OSTM1 or CLCN7 may have severe neurological defects (28). Currently, the only established treatment for the severe forms of osteopetrosis is hematopoietic stem cell transplantation (HSCT). However, the success of the HSCT will depend on the time of diagnosis, i.e., patients undergoing HSCT after the age of 10 months have high prevalence of graft rejection (29). A major issue with HSCT treatment is that it requires HLA-matched donors. For individuals lacking compatible donor, alternative treatment in the future can be gene therapy which has shown promising results in the preclinical trials. For instance, neonatal transplantation of gene-modified HSCs have led to increased bone resorption in oc/oc mice $(30,31)$. Lentiviral-mediated correction of the genetic defect (TCIRG1) have improved osteoclasts activity in vivo $(32,33)$. Last but not least, gene-corrected iPSCs may also be valuable source for testing and developing gene therapy for osteopetrosis (34).

HSCT treatment for TNFSF11 mutations will be ineffective because in this form of osteopetrosis the main defect does not arise from the haematopoietic lineage (35). Osteopetrosis in TNFSF11-deficient patients requires a different treatment approach. Several pre-clinical studies have shown promising results in the treatment of TNFSF11-dependent osteopetrosis. For instance, the administration of synthetic RANKL to Tnfsf $11^{-/-}$mice led to significant improvement of the bone phenotype (36). In addition, several studies are also testing the use of implants and biomimetic scaffolds as source of synthetic RANKL in order to promote osteoclastogenesis in Tnfsf 11 knockout mice (37). These methods need to be further validated before entering clinical trials. 
Additional novel approaches for the treatment of osteopetrosis include gene silencing using small interfering RNAs (38) and interferon gamma (IFN-y) (39) which have shown to be effective in reducing bone mass. Nevertheless, both approaches need further evaluation before they can be brought to the clinic.

\section{Sclerosing Bone Disorders}

Genetic mutations affecting the SOST (chr17q12-21) gene lead to two similar syndromes: sclerosteosis and van Buchem disease, described in detail in previous reviews (10, 40, 41). Sclerosteosis arises from loss-of-function mutations within the SOST gene; whereas, van Buchem disease from deletion of a region $(\sim 52-$ $\mathrm{kb}$ ) downstream of the SOST gene, which is relevant for proper gene expression (42). SOST encodes sclerostin, which is a potent inhibitor of the $\mathrm{Wnt} / \beta$-catenin signaling pathway relevant for osteoblast differentiation and proliferation (43, 44). Moreover, sclerostin incites RANKL secretion and triggers osteoclastogenesis (45). Thus, both diseases are characterized by high bone mass throughout the skeleton. There is no specific therapy for these conditions. The treatment is based on treating symptoms and reducing the severity of complications (40).

The knowledge of the cellular and molecular mechanisms of these rare skeletal disorders have led to new treatment strategies for osteoporosis. The sclerostin monoclonal antibody (Scl-Ab/ Romosozumab), which inhibits the function of sclerostin and enhances bone formation (anabolic compound), is the most recent addition to the osteoporosis set of medications. In the early research stages, $\mathrm{Scl}-\mathrm{Ab}$ treatment has resulted in dosedependent increases in cortical and trabecular bone mass and volume at several skeletal sites in monkeys (46) and rats (47). Similar findings were observed during a Romosozumab Phase I clinical trial of 72 postmenopausal women and healthy men (48). In 2014, the phase II clinical trial of Romosozumab showed significant increases in BMD (49), whereas in Phase III (two years later) it was associated with $73 \%$ lower risk of future vertebral fracture in women with postmenopausal osteoporosis during 24months of follow-up (50). Since 2019, Romosozumab is officially approved for clinical use and is promoted as anabolic agent that stimulates bone formation and decreases bone resorption.

It is worth mentioning that when targeting treatments based on gene function (i.e., gain/loss of function mutations) effects can result in opposing outcomes. For instance, gain-of-function mutations in the LRP5 gene result in drastic increases in bone mass $(51,52)$, while loss-of-function mutations cause decreases in bone mass, i.e., osteoporosis-pseudoglioma syndrome (53, 54). Therefore, strong biological knowledge is needed before embarking on clinical trials as provided by pre-clinical cell and animal models, potentially complemented by the rapidly growing number of genome-wide association studies (GWAS) for complex traits. Further, as described below, GWAS of osteoporosis traits have re-identified variants in genes known to harbor mutations responsible for monogenic conditions. This implies that (1) genes identified by GWAS of complex traits serve as prominent candidates to be scrutinized for underlying "unsolved" monogenic conditions; and (2) genes underlying monogenic conditions which are harboring common variants associated with complex traits provide indication of shared biological pathways with enormous translational potential (55).

\section{WHAT HAVE WE LEARNED FROM COMPLEX SKELETAL TRAITS? Gene Discovery in Osteoporosis}

Osteoporosis is a common complex skeletal disease with a devastating endpoint i.e., fractures. From a genetic perspective osteoporosis is a systemic multifactorial disease caused by a combination of genetic, environmental, and lifestyle factors. Similarly, fracture risk, comprises a very complex trait involving numerous biological and biomechanical processes that are under convoluted genetic and environmental control (55). GWAS have revolutionized the field of genetics of complex traits and common diseases, where osteoporosis is no exception. There are several reviews describing in detail the findings arising from the Genetic Factors of Osteoporosis (GEFOS) consortium, and the UK Biobank (56-58). Currently, there are close to thousands of variants associated with increased risk of osteoporosis $(12,59-62)$. These variants map to relevant bone pathways such as Wnt signaling (LRP5, WNT16, AXIN1, CTNNB1, DKK1, WLS, LRP4, MEF2C, RSPO3, SERP4, SOST, WNT4, WNT5B, EN1), OPG-RANK-RANKL (TNFRSF11B, TNFRSF11A, TNFSF11) and endochondral ossification (PTHLH, RUNX2, SPP1, SOX6), but also novel pathways yet to be explored. Recently, novel genes have been discovered, which are involved in bone metabolism (SLC8A1, PLC1, and ADAMTS5); osteoblast and osteoclast differentiation and activity (CSF1, DUSP5, SMAD3, SMAD9, and CD44); and manganese and calcium absorption (GCKR, DGKD, and SLC30A10), among others (59). Importantly, there is an overlap between the monogenic skeletal conditions and BMD GWAS-identified genes such as GALNT3 [OMIM: 211900], COL1A1 [OMIM: 166210 and 259420], SHFM1 [OMIM: 601285], ESR1 [OMIM: 615363], and LRP4 [OMIM: 212780]; genes implicated in mesenchymal cell differentiation, skeletal development, and bone remodeling and metabolism (55). Remarkably, GWASs on BMD have identified existing or promising drug targets (Figure 1); reflecting the 267-fold enrichment observed across GWAS for validated drug targets in humans (56). However, such relatively high number of discovered drug targets represents a small fraction of the total number of discovered genes. Hence, many novel drug targets are yet to be identified. Recently, two genes identified by GWAS have been proposed as possible novel drug targets for osteoporosis. Kemp et al. (60) using multiple layers of evidence from bioinformatical, functional and biological knowledge have shown GPC6 to play a prominent role in bone biology. $G p c 6^{-/-}$mice is characterized by a high bone mass phenotype and increased cortical bone thickness (60). This gene has also been linked to several essential pathways such as fibroblast growth factor, vascular endothelial growth factor, Hedgehog, and bone morphogenetic protein pathways (64). GPC6 encodes a glypican anchored on the cell membrane in the extracellular matrix and it is relevant for cell signaling. In particular, the heparan sulfate proteoglycans attached to the 


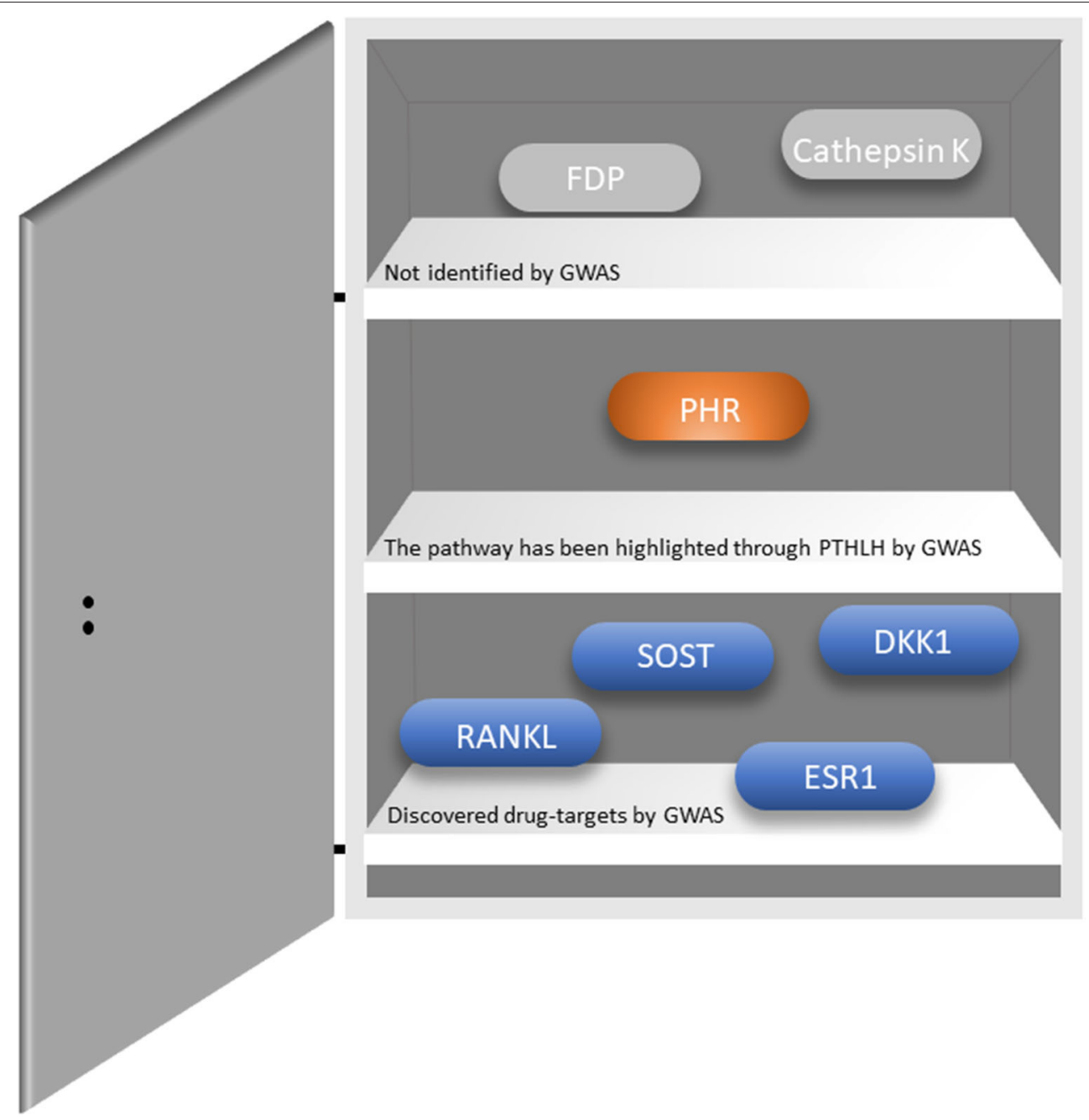

FIGURE 1 | Existing drug targets and whether they have been identified through GWASs. RANKL-Receptor activator of nuclear factor-kB ligand; SOST-sclerostin; DKK1-Dickkopf WNT signaling pathway inhibitor 1; ESR1-Estrogen Receptor 1; PHR-parathyroid hormone receptor; FDP-Farnesyl pyrophosphate. The figure was adapted from Jepsen et al. (63).

GPC6 protein regulate skeletal signaling pathways involved in bone formation and mineralization; thus, representing a potential good drug target. In humans, GPC6 is mainly expressed in the liver and bladder tissue. Given the lack of bone and muscle tissues in publicly available databases there is no evidence for its expression in bone tissue. Nevertheless, GPC6 have been reported to be expressed in osteoblasts and osteocytes in mice (60). Yet another potential drug target identified by GWAS is DAAM2 which regulates canonical Wnt signaling. Further, CRISPR-Cas9mediated DAAM2 knockout models in osteoblast cells lines are shown to exert substantial reduction in inducible mineralization (61). To date, only few genes have been linked with bone mineralization, making this gene particularly interesting as drug target. Nevertheless, further investigations are needed to establish whether GPC6 or DAAM2 truly represent a suitable drug target for osteoporosis.

Before the GWAS era, genetic research was mainly driven by typically underpowered and ill-defined candidate gene studies. For that purpose, the Genetic Markers for Osteoporosis (GENOMOS) consortium was created in order to study "classical" candidate gene polymorphisms such as ESR1, COL1A1, VDR, TGFbeta and LRP5 in relation to osteoporosisrelated outcomes in a well-powered setting of subjects drawn from several study populations around the globe. The main phenotypic outcomes included fracture risk and femoral neck and lumbar spine BMD. The first GENOMOS meta-analysis evaluated three polymorphisms in the ESR1 gene among 18,917 individuals across eight studies and demonstrated no effects on BMD but a modest effect on fracture risk (19-35\% risk reduction for XbaI homozygotes), independent of BMD (65). Next, GENOMOS embarked on studying COL1A1, a gene with long standing candidacy to be involved in the etiology of osteoporosis given its established effect on monogenic forms of skeletal fragility, i.e., osteogenesis imperfecta. GENOMOS observed a significantly lower BMD (0.15SD) in TT homozygotes for the COL1A1 Sp1 polymorphism; (66) as well as a non-significant 
trend toward a $10 \%$ increase in vertebral fracture risk per Tallele. The vitamin $\mathrm{D}$ receptor $(V D R)$ is yet another longstanding candidate gene of osteoporosis, given the crucial role of vitamin D on bone biology. GENOMOS scrutinized 5 VDR polymorphisms (Cdx2, FokI, BsmI, ApaI, TaqI) none of which had evidence for association with either BMD or fracture risk (67). Similarly, none of the 5 tested TGFbeta polymorphisms had effect on BMD or fracture risk (68). Last but not least, GENOMOS did demonstrate an effect for LRP5 coding polymorphisms (Val667Met, Ala1330Val) on BMD as well as on fracture risk, while no effect for the (Ile1062Val) variant in LRP6 (69). Altogether, the meta-analyses of the GENOMOS has provided high degree of evidence of involvement across what were then regarded as high-risk alleles. Of these, only ESR1 and LRP5 have shown to be effectively contributing to explain population variance in risk for osteoporosis. In line with the findings of GENOMOS, none of the classical "osteoporosis" candidate genes, such as VDR and TGFbeta, have been identified in the GWAS meta-analyses of GEFOS as associated with osteoporosis traits. This is not really surprising and stresses the need for well-powered GWAS and the importance of replication of identified genetic associations.

\section{The Potential of Polygenic Risk Scores in Osteoporosis}

Polygenic risk scores (PRSs), which harness findings from GWAS, defined as a sum of genetic variants associated with a specific trait/disease, have recently evolved with the promise of entering and be implemented in the clinic; among other uses to predict an individual's risk of disease. PRSs have been successfully applied across many complex diseases such as type 2 diabetes $(70,71)$, coronary artery disease $(71,72)$, atrial fibrillation $(71)$, inflammatory bowel disease (71), breast cancer and depression; (73) and for some of these conditions characterizing groups of individuals with a risk equivalent to that observed for patients with monogenic mutations (71). Another advantage of the PRS, is that genetic effects are stable across the life-course, therefore holding the potential to predict the onset of disease decades before it occurs. Similarly, genetics can contribute to improved treatment strategies by identifying people who will most benefit from treatment or are at higher risk of adverse effects (74).

In the field of osteoporosis in particular, the use of polygenic risk scores and the Mendelian randomization (MR) approach has brought upon novel insights. In the field of prediction, efforts drawn within the highly-powered setting of the UK Biobank have shown impressive predictive ability. Kim (62) showed that a genetic algorithm using 22,886 SNPs was correlated with heel ultrasound estimated BMD (rho $=0.42)$ and that combining this genetic algorithm with clinical information could improve this correlation $($ rho $=0.5)$. More recently, Forgetta et al. (75) showed that a PRS for heel quantitative ultrasound speed of sound (SOS) - can reassure the low risk of individuals who can safely be excluded from a fracture risk screening program. The "gSOS algorithm" (genetically predicted SOS) employed 21,717 genetic variants that were strongly correlated with standard SOS testing. These findings are important, considering that gSOS proved to have similar predictive power as existing diagnostic tools for osteoporosis i.e., the fracture risk assessment tool (FRAX) with
93.4\% and BMD-based FRAX tests with 98.5\%. These findings suggest that such genetic tool can help to confidently exclude low risk patients from undergoing osteoporosis testing and its associated health care costs.

Just as in other fields, the field of osteoporosis has witnessed how genetic data arising from the GWAS have brought many successes in linking traits and diseases to provide more robust evidence of causality, i.e., when used in a MR framework (76). Randomized Clinical Trials (RCTs) are the gold standard for testing whether exposure is causal for a specific outcome. However, it is not always easy to conduct a RCT. From this perspective, MR has emerged as a promising approach to address this. As our genotypes are randomized by nature (Mendel's second law of independent assortment), the MR approach has been developed to derive more robust evidence of causal association between risk factors and outcomes. MR uses genetic variants that are fixed at birth as instrumental variables in order to derive un-confounded causal effect estimates for modifiable risk factors. Most importantly, performing an MR analysis prior to an RCT can be helpful to predict adverse effects and/or unexpected outcomes, sometimes helping decide if it is worth launching the RCT or not. The use of the MR approach in the field of osteoporosis has provided remarkable insight when scrutinizing the main clinical risk factors of fracture risk. A plethora of risk factors for osteoporosis identified by observational studies have been tested using MR [reviewed by us and others elsewhere $(77,78)]$. Trajanoska et al. (79) showed that BMD is the most important "causally-related" determinant of fracture risk; and that prevention strategies aimed at increasing or maintaining BMD are the most likely to be successful, in contrast to strategies targeting the other traditionally used risk factors. Remarkably, the MR analysis showed how continuous increases in vitamin D levels are not causally related with fracture risk; providing robust evidence showing that indiscriminate vitamin $\mathrm{D}$ supplementation in the general population is unlikely to be effective for the prevention of fracture. This work and the follow-up work by Trajanoska et al. (79) and Cerani et al. (80) showed that calcium intake or calcium levels are also not causally related with fracture risk. The MR analysis also showed that such genetically-derived increase in serum calcium is associated with an increased risk of coronary artery disease (81). These findings imply that widespread calcium supplementation in the general population has a questionable risk/benefit ratio.

\section{Pharmacogenetic Studies in Osteoporosis}

From a clinical perspective there are several pharmacological alternatives for osteoporosis such as bisphosphonates, selective estrogen receptor modulators (SERMs), Hormone replacement therapy (HRT), Teriparatide and Denosumab, among others. About $10-15 \%$ of osteoporosis patients fail to gain bone mass ( $>3 \%)$ despite receiving anti-osteoporotic therapy (8285). Treatment non-response can be due to poor adherence, duration and type of treatment but can also represent a biologically-based failure. Stratified or personalized approaches can be quite relevant for complex disease where an individual's drug response will depend on the combination of markers that regulate absorption, availability, activity and metabolism of drug compounds (86). There is little data about the 
pharmacogenetics of osteoporosis and osteoporotic fractures. In the past, research has mainly focused on few candidate genes, namely the $V D R$, estrogen receptor alpha (ER- $\alpha)$ and COL1A1 genes, which have been investigated with regard to response to osteoporosis-drugs. Long before GWAS, some druggene interaction with bisphosphonates have been postulated. For instance, VDR variants were suggested to modify the effect of alendronate $(87,88)$ or of etidronate $(89)$; the COL1A1 Sp1 polymorphism the effect of etidronate; and variants of genes belonging to the FDPS (mevalonate pathway) the response to amino-bisphosphonate treatment (90-92). Allelic combinations of SOST, PTH, FDPS, and GGPS1 gene variants may also have a role in the individual response to bisphosphonate treatment (93). From the other clinically-relevant perspective of side effects, several polymorphisms mapping within the cytochrome P450-2C (CYP2C8) gene have been associated with increased risk of bisphosphonate-induced osteonecrosis of the jaw in patients with multiple myeloma (94). While illustrating the great potential underlying potential pharmacogenomic investigations, these results need to be interpreted with caution. These studies have been performed in underpowered settings and the tested variants have not been robustly replicated across larger GWAS. Thus, additional evidence from large-scale GWAS aimed at investigating gene $\mathrm{x}$ drug interactions are needed, ideally combined with knowledge from cell and animal models to robustly ascertain possible pharmacogenomics effects. Such pharmacogenomic studies represent a clear knowledge gap in the osteoporosis field.

\section{CURRENT NEEDS IN THE OSTEOPOROSIS TREATMENT FRAMEWORK}

Currently we are facing challenges in osteoporosis care. The operative "decision-to-treat" definition of the disease currently relies on the BMD measurement, transformed to a sex-matched young-adult (peak-bone mass acquisition age) reference in the form of T-scores (95). Pragmatically, individuals with a T-score BMD measurement $<-2.5$ standard deviations (SD) of the BMD of a young adult are classified as having osteoporosis; and due for the initiation of pharmacological treatment and control of risk factors. Individuals with a T-score between -2.5 and -1.0 are classified as having osteopenia and (in absence of clinical risk factors or fractures) pharmacological treatment is not indicated while preventive life style reinforcement is provided. This strategy is extremely suboptimal, as more than $50 \%$ of the fractures occur above the osteoporosis threshold (96). Nevertheless, risk assessments tools that incorporate clinical risk factors on fracture risk over and above the risk provided by $\mathrm{BMD}$, are guiding clinicians in identifying individuals at high fracture risk, so that treatments can be targeted. For example, FRAX (University of Sheffield) integrates clinical risk factors and femoral neck BMD to calculate the 10-year probability of suffering hip fracture and any major osteoporotic fracture (clinical spine, forearm, hip, or shoulder fracture) (97). The predictive ability of FRAX using clinical risk factors and $\mathrm{BMD}$ is effective in helping to identify gradients of risk and make decisions on treatment indication. Nevertheless, the current clinical framework still falls short in its ability to predict accurately response to treatment and providing tailored approaches to maximize the effectiveness of treatments. As discussed above, addition of genetic information to the prediction models can lead to improved risk stratification.

The osteoporosis field possesses multiple pharmacologic therapeutic options at hand, where at least 46 trials (comprising 138,523 participants) have been performed since 1990, including studies on: Bisphosphonates: alendronate (98-106), clodronate (107, 108), etidronate (109), risedronate (110-113), and since more recently zoledronate (114-119), and ibandronate; (120, 120) HRT: estrogen (121) (+progestin) (122) and since more recently, tibolone; (123) SERMs: raloxifen, (124, 125, 125) lasofoxifene (126), bazedoxifene (127, 128), arzoxifene; (129) Calcitonin; (130) Cathepsin K inhibitors: odanacatib; (131) RANKL inhibitor: denosumab; (132-134) Strontium; PTH and analogs: abaloparatide, (135) teriparatide, (136) PTH (1-34) (137, 138) and PTH (1-84); (139) and an Anti-sclerostin antibody: romozosumab (140).

These sets of compounds can be broadly classified into bone resorption inhibitors (including bisphosphonates, HRT, SERMs, Calcitonin and RANKL inhibitor) and bone formation (anabolic) agents (including Anti-Sclerostin antibody, Strontium and PTH/PTH-analogs though the latter two can also exert antiresorption effects). Even with the diverse treatment alternatives, there is a so-called "crisis in the treatment of osteoporosis" i.e., despite the existence of effective drugs to prevent fractures, patients, including those assessed as having a latent high fracture risk and who unequivocally need treatment, are not prescribed osteoporosis medications or they refuse to take them given the uncertainty surrounding the prolonged use of antiresorptive medications and under the fear of ominous rare adverse events (like increased risk of osteonecrosis of the jaw and atypical femur fractures) (141). The current clinical framework lacks crucial information on the biologic and mechanistic pathways underlying the complex nature of fracture risk that are not contemplated in the current T-score based definition of osteoporosis. Altogether, rather than a primary need to embark in the search of "superior" treatments, there is a current need to scrutinize the performance of- and adherence to- current osteoporosis therapies. The best way to do these is by bringing new knowledge resulting in an operative molecular redefinition of osteoporosis that will improve patient care by bringing the field closer to personalized/tailored interventions for the prevention and treatment of the disease.

\section{GENOMIC MEDICINE IN OSTEOPOROSIS PRACTICE}

\section{Future Use of Polygenic Risk Scores (PRS) in Clinical Practice}

Genomic approaches are key to the development of personalized medicine as they contribute to: (1) the understanding of disease at a molecular level; (2) the identification of new biomarkers (quantifiable parameters of disease development 
or disease prognosis); and (3) optimization of therapeutic interventions (drug target discovery, novel indications or response to treatment) (Figure 2). Genomic rather than seeking the identification of a unique treatment beneficial for each individual person, tools of genomic medicine primarily seek subdividing patients into groups based on their "molecular makeup," e.g., using PRS. PRS typically follow a "normal distribution" of risk alleles in the population (Figure 3A), with the majority of individuals tending to have a mean number of risk alleles. Toward both sides of the PRS distribution, a lower fraction of the population consists of individuals with either a very high or very low number of risk alleles. At more extreme truncates of the distribution, disease classification becomes more robust, as it becomes evident that high and low risk alleles underlie (yet not without error) substantial risk differences among groups (Figure 3B); i.e., more risk genotypes (red) cluster to the right (disease category), while non-risk alleles (green) cluster to the left (normal category). Further, the inclusion of SNP annotation to biologic pathways (Figure 3C) can allow pinpointing clusters of patients that theoretically can respond differently to specific pathways targeted by the osteoporosis treatment. This way, the understanding of disease processes at a molecular level, can guide the search for biomarkers of disease risk and differential response to treatments.

Through this so-called patient "stratification" medical interventions can be more successful when fitted to a specific group on patients instead of using the current approach of "one size fits all." This is true for all diseases in general, but of particular great potential for several musculoskeletal conditions (86). In the years to come, genomic research will bring novel insights into molecular mechanisms of osteoporosis and may lead to disease definition reevaluation. In addition, the newly acquired knowledge will redefine the disease-disease relationships by highlighting shared molecular mechanisms that may serve as drug targets for two or more diseases (see below "drug repurposing"). This way, systems biology approaches guided by genomic studies can help to improve decisionmaking in pharmaceutical development in the search for novel biomarkers and therapeutic target.

\section{Drug Discovery and Repurposing}

On average, it takes 12 years and $\sim 1.5$ billion dollars for a new drug to complete all three phases of clinical trials before getting marketing approval. Despite the expensive and time intensive efforts, $90 \%$ of the drugs fail to pass the clinical trials as a result of poor efficacy and safety issues. Nearly $50 \%$ of the failures in Phase II are due to lack of efficacy, whereas $25 \%$ are result of high toxicity; $(142,143)$ even occurring after preclinical models have shown the drugs to be efficient and safe. There are many reasons for the drugs to fail during clinical trials; one of them is that in general drug targets are selected based on their intrinsic "druggability" properties but not their biology. If we don't understand fully the underlying biology of the drug target-disease relationship, unexpected outcomes can occur. Nonetheless, in the past decade positive waves in the drug discovery process have been facilitated by advances in the genomic field supported by a variety of novel computational methods. Nowadays, we have better understanding of the genetic architecture of many diseases and traits and we can utilize this genetic information in drug discovery to pinpoint more efficient and safe drug targets. Nelson et al. have shown that genetic support doubles the drug approval rate (144). These findings were later supported by King et al., which also observed that Phase II and III studies are twice more likely to be successful when genetic data is incorporated in the selection of the drug target (145). For instance, GWAS hits have identified variants in genes encoding pathways targeted by compounds in Phase III or already approved drugs $(146,147)$. Finan et al. (148) have estimated that around 22\% of the 20,300 protein-coding genes annotated in Ensembl version 73 are set to be "druggable." The authors stratified the druggable gene sets into three groups. Tier 1 consists of approved small molecules, biotherapeutic drugs and clinical-case drug candidate; Tier 2 contains a set of genes encoding targets with known bioactive drug-like small-molecule binding partners as well as those with $\geq 50 \%$ identity (over $\geq 75 \%$ of the sequence) with approved drug target; and Tier 3 is a set of genes encoding coding-secreted or extracellular proteins, i.e., proteins with more distant similarity to approved drug targets, and members of key druggable gene families not already included in tier 1 or 2 (148). Mapping the GWAS results to these protein-coding genes may derive new potential drug-targets and is one of our current active areas of research.

Besides discovering novel drug targets, the drug discovery field has directed attention to novel strategies, e.g., drug repositioning or repurposing, meaning using existing "approved" drugs for new indications. In the past, GWAS have also shown to be a good source for drug repositioning as well. Drug repositioning is possible due to how the GWAS field has ascertained the wide-spread presence of pleiotropy, i.e., when one gene (variant) exerts an effect on more than one disease phenotype or complex trait. It is postulated that around 50\% of the discovered GWAS hits have pleiotropic effects (149). Therefore, it is possible for one drug to effectively be used for multiple disease indications. Yet, potential adverse effects need to be explored in detail in the case of antagonistic effects. Nowadays, $35 \%$ of the approved drugs targets modulate G protein-coupled receptors (GPCRs); the largest family of membrane receptors (150). Yet, only $16 \%$ of the $\sim 800$ GPCRs are being currently targeted by existing drugs. Hence, the number of GPCR-targeted drugs, and even types of drugs is expected to dramatically increase in the following years (150).

Across the literature there is lots of evidence for repurposed drugs in other fields. For instance, duloxetine is a selective serotonin and norepinephrine reuptake inhibitor antidepressants (SSNRI) used initially for management of major depressive disorder (MDD). Over the years, new indications for the drug have been proposed, being repurposed for the treatment of fibromyalgia (151), and musculoskeletal and diabetic neuropathic pain $(152,153)$. Next, denosumab, one of the modern anti-resorptive medications to treat osteoporosis, has been used as adjuvant therapy of giant-cell tumor of bone (GCTB) (154). This tumor consists of cluster of neoplastic mononuclear cells and osteoclast like giant cells which express RANK (155). Denosumab inhibits RANKL, thus, supressing 


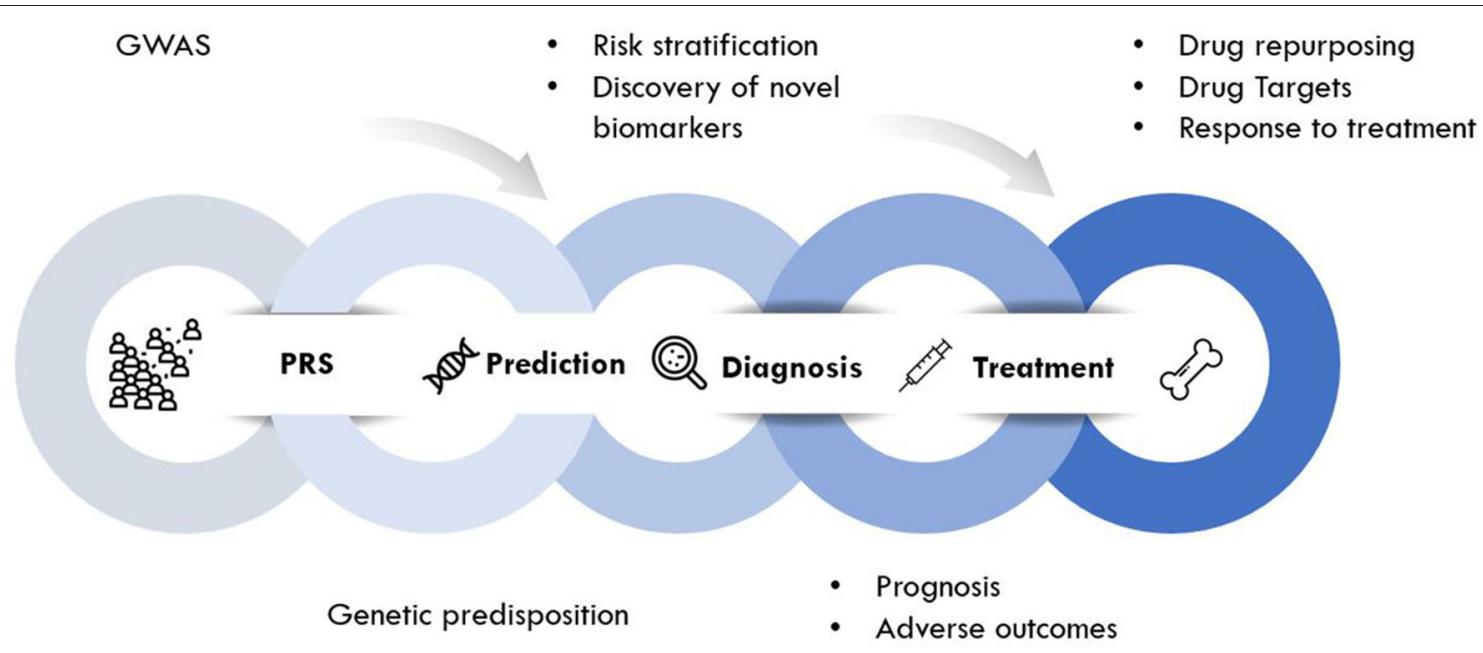

FIGURE 2 | Implementation of genetic information in clinical care.

bone turnover by reducing osteoclast derived bone resorption while also eliminating giant cells. Nowadays, there are also ongoing efforts examining benefits of denosumab therapy on other types of cancer. Such efforts seek pinpointing possible mechanisms that prevent bone metastasis and increase bone metastasis free survival. This hypothesis is based on the knowledge that RANKL is connected with a variety of signaling pathways implicated in immunity and cancer. RANKL and it receptors are essential for lymphoid tissue formation, lymphocyte differentiation, dendritic cell survival and T-cell activation (156, 157); all relevant components for proper functioning of the immune system. Recently it has been shown that concomitant therapy of denosumab and immune checkpoint inhibitors (ICI) may also have beneficial effect on cancer survival and progression $(158,159)$. Therefore, denosumab might have a tremendous clinical impact. In addition, there is ongoing research on the potential anti-cancer mechanisms of bisphosphonates as some (160) but not all (161) clinical trials on breast cancer have reported evidence for anti-tumor effects. This anti-neoplastic effects are plausible, considering that bisphosphonates may alter cellular signaling and responsiveness by modification in the isopentenyl diphosphate metabolism, untimely leading to cell death $(162,163)$. A meta-analysis of 61 clinical trials has also shown bisphosphonates use to be associated with reduced cardiovascular and all-cause mortality (164). Nevertheless, more research is needed before repurposing approaches become common practice, but there is no doubt about the great underlying potential to enrich the therapeutic landscapes of musculoskeletal disease.

Last but not least, other approaches using "-omics" technologies, such as proteomics and metabolomics can provide additional information about the efficacy of new drug targets, elucidate part of the underlying biology, and most importantly, support strategies to anticipate adverse outcomes (165). In addition, many biological molecules interact with each other and cluster based on particular functions or so-called pathways. There are more than 150 different pathway databases, such as Biocarta, KEGG, and Reactome. These resources can help shed additional light on drug-disease mechanisms, decrease the number of false positives in the drug target identification step, prioritize validation, and aid selecting the best target; altogether helping improve the drug discovery success rate (166). As such, there are a variety of computational approaches to detect novel drug-disease relations supported by multitude of databases [reviewed elsewhere $(167,168)]$.

\section{Drug Target Validation Using Mendelian Randomization}

MR analysis can be also performed to investigate potential risk factors or prognostic factors, and to evaluate drug targets (169). With the fast growing pace of the genomic field much better genetic instruments have become available, allowing the expansion of MR studies for the identification and validation of potential drug targets and their adverse effects (170). The genetic variants used as instrumental variants have been implicated as encoding drug targets (170). Nowadays, there are several online platforms which provide detailed information about the underlying biology of the gene of interest, such as the Online Catalog of Human Genes and Genetic Disorders (OMIM). Combining GWAS and OMIM can be a useful way to derive genetic instruments and to test the drug directionality for variety of heritable diseases with available data $(171,172)$. Furthermore, novel methods have been developed to utilize other-omics data in order to detect causal drug targets. The recent focus has been made on proteins, which are the target of most drugs, i.e., using proteomics information to leverage drug identification. Schmidt et al. (173) have developed a novel MR framework for drug validation so called "cis-MR" directed at increasing the precision and robustness of the MR approach. Traditionally, MR uses genetic variants as instrumental variables that are associated with the outcome, independent from other genetic variants in the locus or located elsewhere throughout 


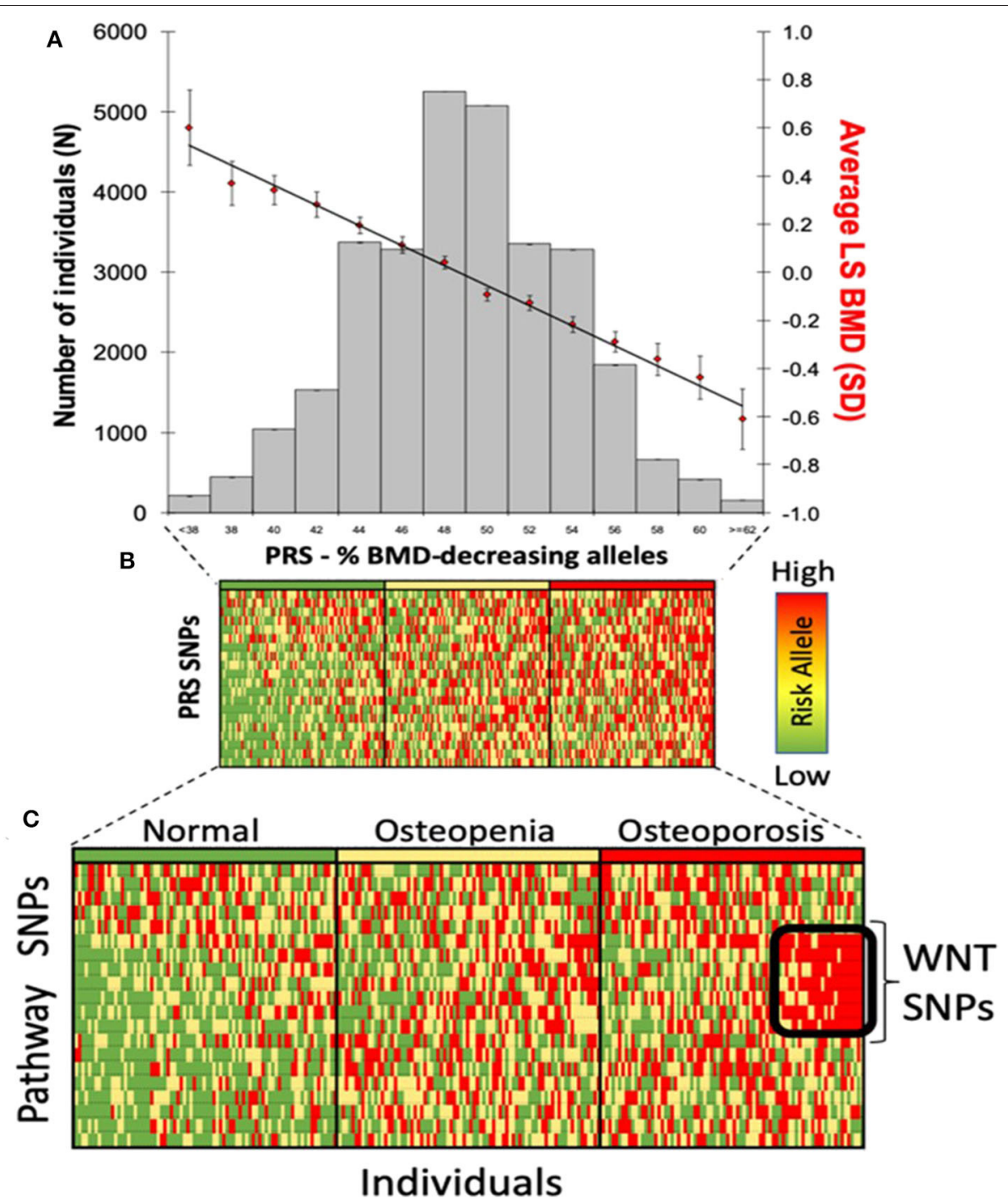

FIGURE 3 | Polygenic risk scores in clinical practice. (A) distribution of PRS in the population; (B) disease risk stratification according to risk allele distribution; and (C) risk stratification using biological pathways.

the genome. In contrast, the cis-MR approach is more stringent, only employing genetic variants located in or in the vicinity of a protein coding genes (173). Recently, work by Zheng et al., have highlighted the important role of cis and trans protein quantitative trait loci (pQTLs) MR analysis, which coupled with evidence for colocalization produces robust evidence of causal protein-phenotype associations as well (174). Next to the aforementioned approaches, phenome-wide MR (MR-PheWAS) can be performed to detect any adverse associations with other clinically relevant outcomes. MR-PheWAS allows testing for a casual association between a selected exposure and a range of phenome-wide disease outcomes; from where we can replicate or discover new relationships between traits or disease outcomes.

A perfect example of a successful MR-drug discovery is the validation of proprotein convertase subtilisin-kexin type 9 (PCSK9). Loss- and gain-of-function genetic variation in this gene region have been associated with low-density lipoprotein cholesterol (LDL-C) an important risk factor for coronary artery disease. Monoclonal antibodies that inhibit PCSK9 have been proposed as a novel drug target to reduce LDL-C and decrease the risk of cardiovascular events; findings that have been robustly confirmed by RCT (175) and other MR studies (176). Additionally, using the MR approach, variations in PCSK9 have been also linked to adverse outcomes such as increased risk of type 2 diabetes (177). These findings demand careful consideration and follow-up of patients using PCSK9 inhibitors to treat hypercholesterolemia, who may be at risk of developing diabetes. In the skeletal field there are other examples of the MR success. Interestingly, observational studies showed in the past that low-doses of cholesterol-lowering statin drugs could be associated with higher BMD and decreased risk of fracture (178, 179). Recent MR studies found genetically lower LDL to be associated with higher BMD levels as well $(180,181)$. In addition, variants mapping to the statins gene-drug target 
(HMGCP) were associated with increase in BMD (180). The effect of HMGCP on bone were established to be partly acting through lowering LDL-C. This indicates that other biologic pathways targeted for other conditions, may affect bone and might have a potential therapeutic implication that needs to be examined in the future. It is important to note that MR cannot test for dose dependent associations. Thus, sometimes it is relevant to couple the evidence from MR with the information coming from well-conducted observational studies. Further, it is important to note that MR studies can inform decision making to launch (or not) RCT about interventions. MR studies can provide evidence to RCTs about aspects of efficacy; unexpected favorable outcomes (with repurposing potential); adverse effects of the evaluated targets; and importantly, the risk of RCT failure. Given the large costs of RCTs, assessing the evidence from MR studies should be considered as part of the planning of any RCT trial. Altogether, while these MR approaches are pending to be widely applied in the field of osteoporosis, MR findings pointing to causal relations between risk factor and outcome, coupled with strong biological understanding of the drug-target disease association, will allow robust validation of drug targets.

\section{CURRENT PROGRESS IN GENE EDITING FOR MONOGENIC AND COMPLEX BONE DISEASES}

Gene editing in clinical practice has major implications in understanding, treating, and preventing deleterious genetic diseases. There are several tools that allow researchers to modify a specific DNA region such as zinc-finer nucleases (ZFNs) (182), transcription activator-like effector nucleases (TALENs) (183), and Clustered Regularly Interspaced Short Palindromic Repeats (CRISPR)/Cas9 (184) [reviewed elsewhere (185, 186)], among others. Compared to the other editing methods, CRISPR/Cas9 has been positioned as faster, cheaper, more precise, and more efficient in selecting and binding to the target DNA sequence. Therefore, the use of the CRISPR/Cas9 technique has become widely spread in the past few years.

Skeletal genetic defects have been typically studied in two animal models, i.e., mouse [reviewed by Maynard et al. (187)] and zebrafish [reviewed by Bergen et al. (188)]. Expectedly, CRISPR/Cas9 gene editing in these mouse and zebrafish models of human skeletal disease has swiftly evolved as comprehensively reviewed, by $\mathrm{Wu}$ et al. (189). To date, CRISPR/Cas9 models have been done for several skeletal disorders such as OI (190),

\section{REFERENCES}

1. Condren ME, Bradshaw MD. Ivacaftor: a novel gene-based therapeutic approach for cystic fibrosis. J Pediatr Pharmacol Ther. (2013) 18:813. doi: 10.5863/1551-6776-18.1.8

2. Aiuti A, Slavin S, Aker M, Ficara F, Deola S, Mortellaro A, et al. Correction of ADA-SCID by stem cell gene therapy combined with nonmyeloablative conditioning. Science. (2002) 296:2410-13. doi: 10.1126/science.1070104 meningocele syndrome (191) and campomelic dysplasia (192). OI type $\mathrm{V}$ is a rare autosomal dominant disease characterized by increased bone fragility, low BMD and increased susceptibility to bone fracture followed by hyperplastic callus formation. OI type $\mathrm{V}$ is caused by heterozygous mutation in the IFITM5 gene which adds 5 amino acid residues (Met-Ala-Leu-Glu-Pro denoted MALEP) on the N-terminus of the BRIL protein (encoded by IFITM5) (193). Rauch et al. (190), generated for the first time, a MALEP-BRIL knock-in mice using CRISPR-cas9. The MALEPBRIL heterozygous mice presented severe skeletal deformities such as short and bent long bones which lack the primary ossification center. Although the current model was genetically identical to human OI type V, it showed additional clinical manifestations. CRISPR/Cas9 animal models have also provided novel insights in the pathology of osteoporosis. In a small scale study (1,625 Han Chinese) variants mapping to ATP6V1H were associated with spine BMD (194). The same study, produced a Atp $6 v 1 h^{+/-}$knockout mice using CRISPR/Cas9 which presented with decreased bone remodeling accompanied by impaired bone formation and increased bone resorption (194). Similar findings were observed in atp6 $1 \mathrm{~h}^{+/-}$zebrafish generated by CRISPR/Cas9 as well (195). Last but not least, there have been several advances in osteogenic gene therapy that has shown promising results in bone remodeling and fracture healing [reviewed elsewhere (196)].

\section{CONCLUSIONS}

Genomic studies are and will continue to be an inexhaustible source of information to better understand the genetic underpinnings of both monogenic and complex bone disorders. In the long run, genetic discoveries will have vast clinical implications, paving the road to precision medicine. Genomic medicine will support clinical-decision making and will dramatically improve disease screening, diagnosis, prognosis and treatment.

\section{AUTHOR CONTRIBUTIONS}

All authors listed have made a substantial, direct and intellectual contribution to the work, and approved it for publication.

\section{FUNDING}

KT and FR were supported by the Netherlands Scientific Organization (NWO) and ZonMW Project Number: NWO/ZONMW-VIDI-0 16-136-367. year follow-up after unilateral subretinal delivery of adeno-associated virus in patients with leber congenital amaurosis type 2. Ophthalmology. (2013) 120:1283-91. doi: 10.1016/j.ophtha.2012.11.048

4. Miesbach W, Meijer K, Coppens M, Kampmann P, Klamroth R, Schutgens R, et al. Gene therapy with adeno-associated virus vector 5human factor IX in adults with hemophilia B. Blood. (2018) 131:102231. doi: 10.1182/blood-2017-09-804419 
5. Cavazzana-Calvo M, Payen E, Negre O, Wang G, Hehir K, Fusil F, et al. Transfusion independence and HMGA2 activation after gene therapy of human $\beta$-thalassaemia. Nature. (2010) 467:318-22. doi: 10.1038/nature09328

6. June $\mathrm{CH}$, Sadelain M. Chimeric antigen receptor therapy. $N$ Engl J Med. (2018) 379:64-73. doi: 10.1056/NEJMra1706169

7. Marini JC, Forlino A, Bächinger HP, Bishop NJ, Byers PH, De Paepe A, et al. Osteogenesis imperfecta. Nat Rev Dis Prim. (2017) 3:119. doi: $10.1038 /$ nrdp. 2017.52

8. Tauer JT, Robinson M-E, Rauch F. Osteogenesis imperfecta: new perspectives from clinical and translational research. JBMR Plus. (2019) 3:e10174. doi: 10.1002/jbm4.10174

9. Wu CC, Econs MJ, DiMeglio LA, Insogna KL, Levine MA, Orchard PJ, et al. Diagnosis and management of osteopetrosis: consensus guidelines from the osteopetrosis working group. J Clin Endocrinol Metab. (2017) 102:3111-23. doi: 10.1210/jc.2017-01127

10. Boudin E, Van Hul W. Sclerosing bone dysplasias. Best Pract Res Clin Endocrinol Metab. (2018) 32:707-23. doi: 10.1016/j.beem.2018.06.003

11. Forlino A, Marini JC. Osteogenesis imperfecta. Lancet. (2016) 387:165771. doi: 10.1016/S0140-6736(15)00728-X

12. Estrada K, Styrkarsdottir U, Evangelou E, Hsu Y-H, Duncan EL, Ntzani $\mathrm{EE}$, et al. Genome-wide meta-analysis identifies 56 bone mineral density loci and reveals 14 loci associated with risk of fracture. Nat Genet. (2012) 44:491-501. doi: 10.1038/ng.2249

13. Chamberlain JR, Schwarze U, Wang PR, Hirata RK, Hankenson KD, Pace $\mathrm{JM}$, et al. Gene targeting in stem cells from individuals with osteogenesis imperfecta. Science. (2004) 303:1198-201. doi: 10.1126/science.1088757

14. Chamberlain JR, Deyle DR, Schwarze U, Wang P, Hirata RK, Li Y, et al. Gene targeting of mutant COL1A2 alleles in mesenchymal stem cells from individuals with osteogenesis imperfecta. Mol Ther. (2008) 16:18793. doi: 10.1038/sj.mt.6300339

15. Deyle DR, Khan IF, Ren G, Wang P-R, Kho J, Schwarze U, et al. Normal collagen and bone production by gene-targeted human osteogenesis imperfecta iPSCs. Mol Ther. (2012) 20:204-13. doi: 10.1038/mt.2011.209

16. Howden S, Hosseini Far H, Motazedian A, Elefanty AG, Stanley EG, Lamandé SR, et al. The use of simultaneous reprogramming and gene correction to generate an osteogenesis imperfecta patient COL1A1 c. 3936 G $>$ T iPSC line and an isogenic control iPSC line. Stem Cell Res. (2019) 38:101453. doi: 10.1016/j.scr.2019.101453

17. Hosseini Far H, Patria YN, Motazedian A, Elefanty AG, Stanley EG, Lamandé SR, et al. Generation of a heterozygous COL1A1 (c.3969_3970insT)osteogenesis imperfecta mutation human iPSC line, MCRIi001-A-1, using CRISPR/Cas9 editing. Stem Cell Res. (2019) 37:101449. doi: 10.1016/j.scr.2019.101449

18. Vanleene M, Saldanha Z, Cloyd KL, Jell G, Bou-Gharios G, Bassett JHD, et al. Transplantation of human fetal blood stem cells in the osteogenesis imperfecta mouse leads to improvement in multiscale tissue properties. Blood. (2011) 117:1053-60. doi: 10.1182/blood-2010-05-287565

19. Jones GN, Moschidou D, Abdulrazzak H, Kalirai BS, Vanleene M, Osatis S, et al. Potential of human fetal chorionic stem cells for the treatment of osteogenesis imperfecta. Stem Cells Dev. (2014) 23:26276. doi: 10.1089/scd.2013.0132

20. Horwitz EM, Prockop DJ, Fitzpatrick LA, Koo WWK, Gordon PL, Neel $\mathrm{M}$, et al. Transplantability and therapeutic effects of bone marrow-derived mesenchymal cells in children with osteogenesis imperfecta. Nat Med. (1999) 5:309-13. doi: 10.1038/6529

21. Götherström C, Westgren M, Shaw SWS, Åström E, Biswas A, Byers PH, et al. Pre- and postnatal transplantation of fetal mesenchymal stem cells in osteogenesis imperfecta: a two-center experience. Stem Cells Transl Med. (2014) 3:255-64. doi: 10.5966/sctm.2013-0090

22. Hill M, Lewis C, Riddington M, Crowe B, DeVile C, David $\mathrm{AL}$, et al. Stakeholder views and attitudes towards prenatal and postnatal transplantation of fetal mesenchymal stem cells to treat osteogenesis imperfecta. Eur J Hum Genet. (2019) 27:1244-53. doi: 10.1038/s41431-019-0387-4

23. Lindahl K, Rubin CJ, Kindmark A, Ljunggren Ö. Allele dependent silencing of COL1A2 using small interfering RNAs. Int J Med Sci. (2008) 5:3615. doi: 10.7150/ijms.5.361
24. Rousseau J, Gioia R, Layrolle P, Lieubeau B, Heymann D, Rossi A, et al. Allele-specific Colla1 silencing reduces mutant collagen in fibroblasts from Brtl mouse, a model for classical osteogenesis imperfecta. Eur J Hum Genet. (2014) 22:667-74. doi: 10.1038/ejhg.2013.198

25. Cleiren E. Albers-Schonberg disease (autosomal dominant osteopetrosis, type II) results from mutations in the ClCN7 chloride channel gene. Hum Mol Genet. (2001) 10:2861-7. doi: 10.1093/hmg/10.25.2861

26. Boudin E, Fijalkowski I, Hendrickx G, Van Hul W. Genetic control of bone mass. Mol Cell Endocrinol. (2016) 432:3-13. doi: 10.1016/j.mce.2015.12.021

27. Ismail EAR, Abul Saad S, Sabry MA. Nephrocalcinosis and urolithiasis in carbonic anhydrase II deficiency syndrome. Eur J Pediatr. (1997) 156:95762. doi: 10.1007/s004310050751

28. Sobacchi C, Villa A, Schulz A, Kornak U. CLCN7-Related Osteopetrosis. (1993). Available online at: http://www.ncbi.nlm.nih.gov/pubmed/20301306 (accessed March 26, 2020).

29. Sobacchi C, Schulz A, Coxon FP, Villa A, Helfrich MH. Osteopetrosis: genetics, treatment and new insights into osteoclast function. Nat Rev Endocrinol. (2013) 9:522-36. doi: 10.1038/nrendo.2013.137

30. Johansson MK, De Vries TJ, Schoenmaker T, Ehinger M, Brun ACM, Fasth A, et al. Hematopoietic stem cell-targeted neonatal gene therapy reverses lethally progressive osteopetrosis in oc/oc mice. Blood. (2007) 109:517885. doi: 10.1182/blood-2006-12-061382

31. Löfvall H, Rothe M, Schambach A, Henriksen K, Richter J, Moscatelli I. Hematopoietic stem cell-targeted neonatal gene therapy with a clinically applicable lentiviral vector corrects osteopetrosis in oc/oc mice. Hum Gene Ther. (2019) 30:1395-404. doi: 10.1089/hum.2019.047

32. Moscatelli I, Thudium CS, Flores C, Schulz A, Askmyr M, Gudmann NS, et al. Lentiviral gene transfer of TCIRG1 into peripheral blood CD34+ cells restores osteoclast function in infantile malignant osteopetrosis. Bone. (2013) 57:1-9. doi: 10.1016/j.bone.2013.07.026

33. Thudium CS, Moscatelli I, Löfvall H, Kertész Z, Montano C, Bjurström CF, et al. Regulation and function of lentiviral vector-mediated TCIRG1 expression in osteoclasts from patients with infantile malignant osteopetrosis: implications for gene therapy. Calcif Tissue Int. (2016) 99:638-48. doi: 10.1007/s00223-016-0187-6

34. Xian X, Moraghebi R, Löfvall H, Fasth A, Henriksen K, Richter $\mathrm{J}$, et al. Generation of gene-corrected functional osteoclasts from osteopetrotic induced pluripotent stem cells. Stem Cell Res Ther. (2020) 11:179. doi: 10.1186/s13287-020-01701-y

35. Sobacchi C, Frattini A, Guerrini MM, Abinun M, Pangrazio A, Susani L, et al. Osteoclast-poor human osteopetrosis due to mutations in the gene encoding RANKL. Nat Genet. (2007) 39:960-62. doi: 10.1038/ng2076

36. Lo Iacono N, Blair HC, Poliani PL, Marrella V, Ficara F, Cassani B, et al. Osteopetrosis rescue upon RANKL administration to Rankl-/- mice: a new therapy for human RANKL-dependent ARO. J Bone Miner Res. (2012) 27:2501-10. doi: 10.1002/jbmr.1712

37. Menale C, Campodoni E, Palagano E, Mantero S, Erreni M, Inforzato A, et al. Mesenchymal stromal cell-seeded biomimetic scaffolds as a factory of soluble RANKL in rankl-deficient osteopetrosis. Stem Cells Transl Med. (2019) 8:22-34. doi: 10.1002/sctm.18-0085

38. Capulli M, Maurizi A, Ventura L, Rucci N, Teti A. Effective small interfering RNA therapy to treat CLCN7-dependent autosomal dominant osteopetrosis type 2. Mol Ther Nucleic Acids. (2015) 4:e248. doi: 10.1038/mtna.2015.21

39. Alam I, Gray AK, Acton D, Gerard-O'Riley RL, Reilly AM, Econs MJ. Interferon Gamma, but not calcitriol improves the osteopetrotic phenotypes in ADO2 mice. J Bone Miner Res. (2015) 30:2005-13. doi: 10.1002/jbmr.2545

40. van Lierop AH, Appelman-Dijkstra NM, Papapoulos SE. Sclerostin deficiency in humans. Bone. (2017) 96:5162. doi: 10.1016/j.bone.2016.10.010

41. Van Lierop AH, Hamdy NAT, Van Egmond ME, Bakker E, Dikkers FG, Papapoulos SE. Van Buchem disease: clinical, biochemical, and densitometric features of patients and disease carriers. J Bone Miner Res. (2013) 28:848-54. doi: 10.1002/jbmr. 1794

42. Balemans W, Patel N, Ebeling M, Van Hul E, Wuyts W, Lacza C, et al. Identification of a $52 \mathrm{~kb}$ deletion downstream of the SOST gene in patients with van Buchem disease. J Med Genet. (2002) 39:9197. doi: 10.1136/jmg.39.2.91 
43. Poole KES, van Bezooijen RL, Loveridge N, Hamersma H, Papapoulos SE, Löwik CW, et al. Sclerostin is a delayed secreted product of osteocytes that inhibits bone formation. FASEB J. (2005) 19:184244. doi: 10.1096/fj.05-4221fje

44. Li X, Zhang Y, Kang H, Liu W, Liu P, Zhang J, et al. Sclerostin binds to LRP5/6 and antagonizes canonical Wnt signaling. J Biol Chem. (2005) 280:19883-7. doi: 10.1074/jbc.M413274200

45. Tu X, Delgado-Calle J, Condon KW, Maycas M, Zhang H, Carlesso $\mathrm{N}$, et al. Osteocytes mediate the anabolic actions of canonical Wnt $/ \beta$ catenin signaling in bone. Proc Natl Acad Sci USA. (2015) 112:E47886. doi: $10.1073 /$ pnas. 1409857112

46. Ominsky MS, Vlasseros F, Jolette J, Smith SY, Stouch B, Doellgast G, et al. Two doses of sclerostin antibody in cynomolgus monkeys increases bone formation, bone mineral density, and bone strength. J Bone Miner Res. (2010) 25:948-59. doi: 10.1002/jbmr.14

47. Tian XY, Jee WSS, Li X, Paszty C, Ke HZ. Sclerostin antibody increases bone mass by stimulating bone formation and inhibiting bone resorption in a hindlimb-immobilization rat model. Bone. (2011) 48:197201. doi: 10.1016/j.bone.2010.09.009

48. Padhi D, Jang G, Stouch B, Fang L, Posvar E. Single-dose, placebo-controlled, randomized study of AMG 785, a sclerostin monoclonal antibody. J Bone Miner Res. (2011) 26:19-26. doi: 10.1002/jbmr.173

49. McClung MR, Grauer A, Boonen S, Bolognese MA, Brown JP, Diez-Perez A, et al. Romosozumab in postmenopausal women with low bone mineral density. N Engl J Med. (2014) 370:412-20. doi: 10.1056/NEJMoa1305224

50. Cosman F, Crittenden DB, Adachi JD, Binkley N, Czerwinski E, Ferrari S, et al. Romosozumab treatment in postmenopausal women with osteoporosis. N Engl J Med. (2016) 375:1532-43. doi: 10.1056/NEJMoa1607948

51. Boyden LM, Mao J, Belsky J, Mitzner L, Farhi A, Mitnick MA, et al. High bone density due to a mutation in LDL-receptor-related protein 5. $\mathrm{N} \mathrm{Engl} \mathrm{J}$ Med. (2002) 346:1513-21. doi: 10.1056/NEJMoa013444

52. Little RD, Folz C, Manning SP, Swain PM, Zhao S-C, Eustace B, et al. A mutation in the LDL receptor-related protein 5 gene results in the autosomal dominant high-bone-mass trait. Am J Hum Genet. (2002) 70:119. doi: $10.1086 / 338450$

53. Levasseur $\mathrm{R}$, Lacombe $\mathrm{D}$, De Vernejoul MC. LRP5 mutations in osteoporosis-pseudoglioma syndrome and high-bone-mass disorders. $J t$ Bone Spine. (2005) 72:207-14. doi: 10.1016/j.jbspin.2004.10.008

54. Gong Y, Slee RB, Fukai N, Rawadi G, Roman-Roman S, Reginato AM, et al. LDL receptor-related protein 5 (LRP5) affects bone accrual and eye development. Cell. (2001) 107:513-23. doi: 10.1016/s0092-8674(01)00571-2

55. Rivadeneira F, Mäkitie O. Osteoporosis and bone mass disorders: from gene pathways to treatments. Trends Endocrinol Metab. (2016) 27:26281. doi: $10.1016 /$ j.tem.2016.03.006

56. Richards JB, Zheng H-F, Spector TD. Genetics of osteoporosis from genomewide association studies: advances and challenges. Nat Rev Genet. (2012) 13:576-88. doi: 10.1038/nrg3315

57. Trajanoska K, Rivadeneira F. The genetic architecture of osteoporosis and fracture risk. Bone. (2019) 126:2-10. doi: 10.1016/j.bone.2019.04.005

58. Koromani F, Trajanoska K, Rivadeneira F, Oei L. Recent advances in the genetics of fractures in osteoporosis. Front Endocrinol. (2019) 10:337. doi: 10.3389/fendo.2019.00337

59. Medina-Gomez C, Kemp JP, Trajanoska K, Luan J, Chesi A, Ahluwalia TS, et al. Life-course genome-wide association study meta-analysis of total body BMD and assessment of age-specific effects. Am J Hum Genet. (2018) 102:88-102. doi: 10.1016/j.ajhg.2017.12.005

60. Kemp JP, Morris JA, Medina-Gomez C, Forgetta V, Warrington NM, Youlten SE, et al. Identification of 153 new loci associated with heel bone mineral density and functional involvement of GPC6 in osteoporosis. Nat Genet. (2017) 49:1468-75. doi: 10.1038/ng.3949

61. Morris JA, Kemp JP, Youlten SE, Laurent L, Logan JG, Chai RC, et al. An atlas of genetic influences on osteoporosis in humans and mice. Nat Genet. (2019) 51:258-66. doi: 10.1038/s41588-018-0302-x

62. Kim SK. Identification of 613 new loci associated with heel bone mineral density and a polygenic risk score for bone mineral density, osteoporosis and fracture. PLoS ONE. (2018) 13:e0200785. doi: 10.1371/journal.pone. 0200785
63. Jepsen KJ, Schlecht SH, Kozloff KM. Are we taking full advantage of the growing number of pharmacological treatment options for osteoporosis? Curr Opin Pharmacol. (2014) 16:64-71. doi: 10.1016/j.coph.2014.03.006

64. Malinauskas T, Jones EY. Extracellular modulators of Wnt signalling. Curr Opin Struct Biol. (2014) 29:77-84. doi: 10.1016/j.sbi.2014.10.003

65. Ioannidis JPA, Ralston SH, Bennett ST, Brandi ML, Grinberg D, Karassa FB, et al. Differential genetic effects of ESR1 gene polymorphisms on osteoporosis outcomes. J Am Med Assoc. (2004) 292:2105-14. doi: 10.1001/jama.292.17.2105

66. Ralston SH, Uitterlinden AG, Brandi ML, Balcells S, Langdahl BL, Lips P, et al. Large-scale evidence for the effect of the COLIA1 Sp1 polymorphism on osteoporosis outcomes: the GENOMOS study. PLoS Med. (2006) 3:e90. doi: 10.1371/journal.pmed.0030090

67. Uitterlinden AG, Ralston SH, Brandi ML, Carey AH, Grinberg D, Langdahl $\mathrm{BL}$, et al. The association between common vitamin $\mathrm{D}$ receptor gene variations and osteoporosis: a participant-level meta-analysis. Ann Intern Med. (2006) 145:255-64. doi: 10.7326/0003-4819-145-4-200608150-00005

68. Langdahl BL, Uitterlinden AG, Ralston SH, Trikalinos TA, Balcells S, Brandi ML, et al. Large-scale analysis of association between polymorphisms in the transforming growth factor beta 1 gene (TGFB1) and osteoporosis: the GENOMOS study. Bone. (2008) 42:969-81. doi: 10.1016/j.bone.2007.11.007

69. van Meurs JBJ, Trikalinos TA, Ralston SH, Balcells S, Brandi ML, Brixen K, et al. Large-scale analysis of association between variants and osteoporosis. JAMA. (2008) 299:1277. doi: 10.1001/jama.299.11.1277

70. Bonifacio E, Beyerlein A, Hippich M, Winkler C, Vehik K, Weedon MN, et al. Genetic scores to stratify risk of developing multiple islet autoantibodies and type 1 diabetes: a prospective study in children. PLoS Med. (2018) 15:e1002548. doi: 10.1371/journal.pmed.1002548

71. Khera AV, Chaffin M, Aragam KG, Haas ME, Roselli C, Choi SH, et al. Genome-wide polygenic scores for common diseases identify individuals with risk equivalent to monogenic mutations. Nat Genet. (2018) 50:121924. doi: 10.1038/s41588-018-0183-z

72. Wünnemann F, Sin Lo K, Langford-Avelar A, Busseuil D, Dubé MP, Tardif JC, et al. Validation of genome-wide polygenic risk scores for coronary artery disease in french canadians. Circ Genomic Precis Med. (2019) 12:e002481. doi: 10.1161/CIRCGEN.119.002481

73. Halldorsdottir T, Piechaczek C, De Matos APS, Czamara D, Pehl V, Wagenbuechler P, et al. Polygenic risk: predicting depression outcomes in clinical and epidemiological cohorts of youths. Am J Psychiatry. (2019) 176:615-25. doi: 10.1176/appi.ajp.2019.18091014

74. Zeggini E, Gloyn AL, Barton AC, Wain LV. Translational genomics and precision medicine: moving from the lab to the clinic. Science. (2019) 365:1409-13. doi: 10.1126/science.aax4588

75. Forgetta V, Keller-Baruch J, Forest M, Durand A, Bhatnagar S, Kemp JP, et al. Development of a polygenic risk score to improve screening for fracture risk: a genetic risk prediction study. PLoS Med. (2020) 17:e1003152. doi: 10.1371/journal.pmed.1003152

76. Smith GD, Ebrahim S. "Mendelian randomization": can genetic epidemiology contribute to understanding environmental determinants of disease? Int J Epidemiol. (2003) 32:1-22. doi: 10.1093/ije/dyg070

77. Trajanoska K, Rivadeneira F. Using mendelian randomization to decipher mechanisms of bone disease. Curr Osteoporos Rep. (2018) 16:53140. doi: 10.1007/s11914-018-0467-3

78. Zheng J, Frysz M, Kemp JP, Evans DM, Davey Smith G, Tobias JH. Use of Mendelian randomization to examine causal inference in osteoporosis. Front Endocrinol. (2019) 10:807. doi: 10.3389/fendo.2019.00807

79. Trajanoska K, Morris JA, Oei L, Zheng H-F, Evans DM, Kiel DP, et al. Assessment of the genetic and clinical determinants of fracture risk: genome wide association and mendelian randomisation study. BMJ. (2018) 362:k3225. doi: 10.1136/bmj.k3225

80. Cerani A, Zhou S, Forgetta V, Morris JA, Trajanoska K, Rivadeneira F, et al. Genetic predisposition to increased serum calcium, bone mineral density, and fracture risk in individuals with normal calcium levels: mendelian randomisation study. BMJ. (2019) 366:14410. doi: 10.1136/bmj.14410

81. Larsson SC, Burgess S, Michaëlsson K. Association of genetic variants related to serum calcium levels with coronary artery disease and myocardial infarction. JAMA. (2017) 318:371-80. doi: 10.1001/jama.2017.8981 
82. Francis RM. Non-response to osteoporosis treatment. $J \mathrm{Br}$ Menopause Soc. (2004) 10:76-80. doi: 10.1258/13621800477420 2409

83. Gallagher JC, Rosen CJ, Chen P, Misurski DA, Marcus R. Response rate of bone mineral density to teriparatide in postmenopausal women with osteoporosis. Bone. (2006) 39:1268-75. doi: 10.1016/j.bone.2006.06.007

84. Ramchand SK, David NL, Leder ZB, Tsai JN. Bone mineral density response with denosumab in combination with standard or high-dose teriparatide: the DATA-HD RCT. J Clin Endocrinol Metab. 105:890-7. doi: $10.1210 /$ clinem/dgz163

85. Leder BZ, O’Dea LSL, Zanchetta JR, Kumar P, Banks K, McKay $\mathrm{K}$, et al. Effects of abaloparatide, a human parathyroid hormonerelated peptide analog, on bone mineral density in postmenopausal women with osteoporosis. J Clin Endocrinol Metab. (2015) 100:697706. doi: 10.1210/jc.2014-3718

86. Hocking LJ, Rivadeneira F. Stratified medicine approaches for the treatment of musculoskeletal disorders. Curr Opin Pharmacol. (2014) 16:12732. doi: 10.1016/j.coph.2014.05.003

87. Palomba S, Numis FG, Mossetti G, Rendina D, Vuotto P, Russo T, et al. Effectiveness of alendronate treatment in postmenopausal women with osteoporosis: relationship with Bsml vitamin D receptor genotypes. Clin Endocrinol. (2003) 58:365-71. doi: 10.1046/j.1365-2265.2003.01724.x

88. Palomba S, Orio F, Russo T, Falbo A, Tolino A, Manguso F, et al. BsmI vitamin D receptor genotypes influence the efficacy of antiresorptive treatments in postmenopausal osteoporotic women. A 1-year multicenter, randomized and controlled trial. Osteoporos Int. (2005) 16:943-52. doi: 10.1007/s00198-004-1800-5

89. Marc J, Prezelj J, Komel R, Kocijancic A. VDR genotype and response to etidronate therapy in late postmenopausal women. Osteoporos Int. (1999) 10:303-6. doi: 10.1007/s001980050231

90. Marini F, Falchetti A, Silvestri S, Bagger Y, Luzi E, Tanini A, et al. Modulatory effect of farnesyl pyrophosphate synthase (FDPS) rs2297480 polymorphism on the response to long-term amino-bisphosphonate treatment in postmenopausal osteoporosis. Curr Med Res Opin. (2008) 24:2609-15. doi: 10.1185/03007990802352894

91. Qureshi AM, Herd RJ, Blake GM, Fogelman I, Ralston SH. Colial Sp1 polymorphism predicts response of femoral neck bone density to cyclical etidronate therapy. Calcif Tissue Int. (2002) 70:158-63. doi: 10.1007/s00223-001-1035-9

92. Olmos JM, Zarrabeitia MT, Hernández JL, Sãudo C, González-Macías J, Riancho JA. Common allelic variants of the farnesyl diphosphate synthase gene influence the response of osteoporotic women to bisphosphonates. Pharmacogenomics J. (2012) 12:227-32. doi: 10.1038/tpj.2010.88

93. Marozik P, Alekna V, Rudenko E, Tamulaitiene M, Rudenka A, Mastaviciute $\mathrm{A}$, et al. Bone metabolism genes variation and response to bisphosphonate treatment in women with postmenopausal osteoporosis. PLOS ONE. (2019) 14:e0221511. doi: 10.1371/journal.pone.0221511

94. Sarasquete ME, García-Sanz R, Marín L, Alcoceba M, Chillón MC, Balanzategui A, et al. Bisphosphonate-related osteonecrosis of the jaw is associated with polymorphisms of the cytoehrome P450 CYP2C8 in multiple myeloma: A genome-wide single nucleotide polymorphism analysis. Blood. (2008) 112:2709-12. doi: 10.1182/blood-2008-04-147884

95. Kanis JA, Melton LJ, Christiansen C, Johnston CC, Khaltaev N. The diagnosis of osteoporosis. J Bone Miner Res. (1994) 9:113741. doi: 10.1002/jbmr.5650090802

96. Trajanoska K, Schoufour JD, de Jonge EAL, Kieboom BCT, Mulder M, Stricker BH, et al. Fracture incidence and secular trends between 1989 and 2013 in a population based cohort: the rotterdam study. Bone. (2018) 114:116-24. doi: 10.1016/j.bone.2018.06.004

97. Kanis JA, Johnell O, Oden A, Johansson H, McCloskey E. FRAX ${ }^{\mathrm{TM}}$ and the assessment of fracture probability in men and women from the UK. Osteoporos Int. (2008) 19:385-97. doi: 10.1007/s00198-007-0543-5

98. Yan Y, Wang W, Zhu H, Li M, Liu J, Luo B, et al. The efficacy and tolerability of once-weekly alendronate $70 \mathrm{mg}$ on bone mineral density and bone turnover markers in postmenopausal Chinese women with osteoporosis. $J$ Bone Miner Metab. (2009) 27:471-8. doi: 10.1007/s00774-009-0057-7

99. Greenspan SL, Schneider DL, McClung MR, Miller PD, Schnitzer $\mathrm{TJ}$, Bonin R, et al. Alendronate improves bone mineral density in elderly women with osteoporosis residing in long-term care facilities: a randomized, double-blind, placebo-controlled trial. Ann Intern Med. (2002) 136:742-6. doi: 10.7326/0003-4819-136-10-200205210-0 0009

100. Orwoll E, Ettinger M, Weiss S, Miller P, Kendler D, Graham J, et al. Alendronate for the treatment of osteoporosis in men. N Engl J Med. (2000) 343:604-10. doi: 10.1056/NEJM200008313430902

101. Hosking D, Chilvers CED, Christiansen C, Ravn P, Wasnich R, Ross $\mathrm{P}$, et al. Prevention of bone loss with alendronate in postmenopausal women under 60 years of age. $N$ Engl J Med. (1998) 338:48592. doi: 10.1056/NEJM199802193380801

102. Cummings SR, Black DM, Thompson DE, Applegate WB, Barrett-Connor E, Musliner TA, et al. Effect of alendronate on risk of fracture in women with low bone density but without vertebral fractures: results from the fracture intervention trial. JAMA. (1998) 280:2077-82. doi: 10.1001/jama.280.24.2077

103. Black DM, Cummings SR, Karpf DB, Cauley JA, Thompson DE, Nevitt MC, et al. Randomised trial of effect of alendronate on risk of fracture in women with existing vertebral fractures. Fracture intervention trial research group. Lancet. (1996) 348:1535-41. doi: 10.1016/S0140-6736(96)07088-2

104. Liberman UA, Weiss SR, Bröll J, Minne HW, Quan H, Bell NH, et al. Effect of oral alendronate on bone mineral density and the incidence of fractures in postmenopausal osteoporosis. N Engl J Med. (1995) 333:143744. doi: 10.1056/NEJM199511303332201

105. Pols HAP, Felsenberg D, Hanley DA, Štepán J, Muñoz-Torres M, Wilkin TJ, et al. Multinational, placebo-controlled, randomized trial of the effects of alendronate on bone density and fracture risk in postmenopausal women with low bone mass: results of the FOSIT study. Osteoporos Int. (1999) 9:461-8. doi: 10.1007/PL00004171

106. Bone HG, Downs RW, Tucci JR, Harris ST, Weinstein RS, Licata $\mathrm{AA}$, et al. Dose-response relationships for alendronate treatment in osteoporotic elderly women 1. J Clin Endocrinol Metab. (1997) 82:26574. doi: $10.1210 /$ jc.82.1.265

107. McCloskey EV, Beneton M, Charlesworth D, Kayan K, DeTakats D, Dey $\mathrm{A}$, et al. Clodronate reduces the incidence of fractures in communitydwelling elderly women unselected for osteoporosis: results of a doubleblind, placebo-controlled randomized study. J Bone Miner Res. (2007) 22:135-41. doi: 10.1359/jbmr.061008

108. McCloskey E, Selby P, Davies M, Robinson J, Francis RM, Adams J, et al. Clodronate reduces vertebral fracture risk in women with postmenopausal or secondary osteoporosis: results of a double-blind, placebo-controlled 3-year study. J Bone Miner Res. (2004) 19:728-36. doi: 10.1359/jbmr.040116

109. Watts NB, Harris ST, Genant HK, Wasnich RD, Miller PD, Jackson RD, et al. Intermittent cyclical etidronate treatment of postmenopausal osteoporosis. N Engl J Med. (1990) 323:73-9. doi: 10.1056/NEJM199007123230201

110. McClung MR, Geusens P, Miller PD, Zippel H, Bensen WG, Roux C, et al. Effect of risedronate on the risk of hip fracture in elderly women. Hip intervention program study group. N Engl J Med. (2001) 344:33340. doi: 10.1056/NEJM200102013440503

111. Reginster J, Minne HW, Sorensen OH, Hooper M, Roux C, Brandi ML, et al. Randomized trial of the effects of risedronate on vertebral fractures in women with established postmenopausal osteoporosis. Vertebral efficacy with risedronate therapy (VERT) study group. Osteoporos Int. (2000) 11:8391. doi: $10.1007 / \mathrm{s} 001980050010$

112. Harris ST, Watts NB, Genant HK, McKeever CD, Hangartner T, Keller M, et al. Effects of risedronate treatment on vertebral and nonvertebral fractures in women with postmenopausal osteoporosis: a randomized controlled trial. Vertebral efficacy with risedronate therapy (VERT) study group. JAMA. (1999) 282:1344-52. doi: 10.1001/jama.282.14.1344

113. Hooper MJ, Ebeling PR, Roberts AP, Graham JJ, Nicholson GC, D'Emden $\mathrm{M}$, et al. Risedronate prevents bone loss in early postmenopausal women: a prospective randomized, placebo-controlled trial. Climacteric. (2005) 8:25162. doi: 10.1080/13697130500118126

114. Nakamura T, Fukunaga M, Nakano T, Kishimoto H, Ito M, Hagino $\mathrm{H}$, et al. Efficacy and safety of once-yearly zoledronic acid in Japanese patients with primary osteoporosis: two-year results from a randomized placebo-controlled double-blind study (ZOledroNate treatment in efficacy to osteoporosis; ZONE study). Osteoporos Int. (2017) 28:389-98. doi: 10.1007/s00198-016-3736-y 
115. Greenspan SL, Perera S, Ferchak MA, Nace DA, Resnick NM. Efficacy and safety of single-dose zoledronic acid for osteoporosis in frail elderly women a randomized clinical trial. JAMA Intern Med. (2015) 175:91321. doi: 10.1001/jamainternmed.2015.0747

116. Boonen S, Reginster J-Y, Kaufman J-M, Lippuner K, Zanchetta J, Langdahl $\mathrm{B}$, et al. Fracture risk and zoledronic acid therapy in men with osteoporosis. N Engl J Med. (2012) 367:1714-23. doi: 10.1056/NEJMoa1204061

117. Lyles KW, Colón-Emeric CS, Magaziner JS, Adachi JD, Pieper CF, Mautalen $\mathrm{C}$, et al. Zoledronic acid and clinical fractures and mortality after hip fracture. N Engl J Med. (2007) 357:1799-809. doi: 10.1056/NEJMoa074941

118. Black DM, Delmas PD, Eastell R, Reid IR, Boonen S, Cauley JA, et al. Onceyearly zoledronic acid for treatment of postmenopausal osteoporosis. $\mathrm{N} \mathrm{Engl}$ J Med. (2007) 356:1809-22. doi: 10.1056/NEJMoa067312

119. Reid IR, Brown JP, Burckhardt P, Horowitz Z, Richardson P, Trechsel U, et al. Intravenous zoledronic acid in postmenopausal women with low bone mineral density. N Engl J Med. (2002) 346:653-61. doi: 10.1056/NEJMoa011807

120. Recker R, Stakkestad JA, Chesnut CH, Christiansen C, Skag A, Hoiseth A, et al. Insufficiently dosed intravenous ibandronate injections are associated with suboptimal antifracture efficacy in postmenopausal osteoporosis. Bone. (2004) 34:890-9. doi: 10.1016/j.bone.2004.01.008

121. Jackson RD, Wactawski-Wende J, LaCroix AZ, Pettinger M, Yood RA, Watts NB, et al. Effects of conjugated equine estrogen on risk of fractures and $\mathrm{BMD}$ in postmenopausal women with hysterectomy: results from the women's health initiative randomized trial. J Bone Miner Res. (2006) 21:81728. doi: 10.1359/jbmr.060312

122. Cauley JA, Robbins J, Chen Z, Cummings SR, Jackson RD, LaCroix AZ, et al. Effects of estrogen plus progestin on risk of fracture and bone mineral density: the women's health initiative randomized trial. J Am Med Assoc. (2003) 290:1729-38. doi: 10.1001/jama.290.13.1729

123. Cummings SR, Ettinger B, Delmas PD, Kenemans P, Stathopoulos V, Verweij P, et al. The effects of tibolone in older postmenopausal women. $N$ Engl J Med. (2008) 359:697-708. doi: 10.1056/NEJMoa0800743

124. Reid IR, Eastell R, Fogelman I, Adachi JD, Rosen A, Netelenbos C, et al. A comparison of the effects of raloxifene and conjugated equine estrogen on bone and lipids in healthy postmenopausal women. Arch Intern Med. (2004) 164:871-9. doi: 10.1001/archinte.164.8.871

125. Morii H, Ohashi Y, Taketani Y, Fukunaga M, Nakamura T, Itabashi A, et al. Effect of raloxifene on bone mineral density and biochemical markers of bone turnover in Japanese postmenopausal women with osteoporosis: results from a randomized placebo-controlled trial. Osteoporos Int. (2003) 14:793-800. doi: 10.1007/s00198-003-1424-1

126. Cummings SR, Ensrud K, Delmas PD, LaCroix AZ, Vukicevic S, Reid DM, et al. Lasofoxifene in postmenopausal women with osteoporosis. N Engl J Med. (2010) 362:686-96. doi: 10.1056/NEJMoa0808692

127. Itabashi A, Yoh K, Chines AA, Miki T, Takada M, Sato H, et al. Effects of bazedoxifene on bone mineral density, bone turnover, and safety in postmenopausal japanese women with osteoporosis. J Bone Miner Res. (2011) 26:519-29. doi: 10.1002/jbmr.252

128. Silverman SL, Christiansen C, Genant HK, Vukicevic S, Zanchetta JR, De Villiers TJ, et al. Efficacy of bazedoxifene in reducing new vertebral fracture risk in postmenopausal women with osteoporosis: results from a 3-year, randomized, placebo-, and active-controlled clinical trial. J Bone Min Res. (2008) 23:1923-34. doi: 10.1359/jbmr.080710

129. Cummings SR, McClung M, Reginster JY, Cox D, Mitlak B, Stock J, et al. Arzoxifene for prevention of fractures and invasive breast cancer in postmenopausal women. J Bone Miner Res. (2011) 26:397404. doi: 10.1002/jbmr.191

130. Chesnut CH, Silverman S, Andriano K, Genant H, Gimona A, Harris $\mathrm{S}$, et al. A randomized trial of nasal spray salmon calcitonin in postmenopausal women with established osteoporosis: the prevent recurrence of osteoporotic fractures study. Am J Med. (2000) 109:267-76. doi: 10.1016/S0002-9343(00)00490-3

131. Bonnick S, De Villiers T, Odio A, Palacios S, Chapurlat R, DaSilva C, et al. Effects of odanacatib on BMD and safety in the treatment of osteoporosis in postmenopausal women previously treated with alendronate: a randomized placebo-controlled trial. J Clin Endocrinol Metab. (2013) 98:4727-35. doi: 10.1210/jc.2013-2020
132. Nakamura T, Matsumoto T, Sugimoto T, Hosoi T, Miki T, Gorai I, et al. Clinical trials express: fracture risk reduction with denosumab in Japanese postmenopausal women and men with osteoporosis: denosumab fracture intervention randomized placebo controlled trial (DIRECT). J Clin Endocrinol Metab. (2014) 99:2599-607. doi: 10.1210/jc.2013-4175

133. Cummings SR, Martin JS, McClung MR, Siris ES, Eastell R, Reid IR, et al. Denosumab for prevention of fractures in postmenopausal women with osteoporosis. N Engl J Med. (2009) 361:756-65. doi: 10.1056/NEJMoa0809493

134. Bone HG, Bolognese MA, Yuen CK, Kendler DL, Wang H, Liu Y, et al. Effects of denosumab on bone mineral density and bone turnover in postmenopausal women. J Clin Endocrinol Metab. (2008) 93:214957. doi: 10.1210/jc.2007-2814

135. Miller PD, Hattersley G, Riis BJ, Williams GC, Lau E, Russo LA, et al. Effect of abaloparatide vs placebo on newvertebral fractures in postmenopausalwomen with osteoporosis a randomized clinical trial. JAMA. (2016) 316:722-33. doi: 10.1001/jama.2016.11136

136. Fujita T, Fukunaga M, Itabashi A, Tsutani K, Nakamura T. Once-weekly injection of low-dose teriparatide $(28.2 \mu \mathrm{g})$ reduced the risk of vertebral fracture in patients with primary osteoporosis. Calcif Tissue Int. (2014) 94:170-5. doi: 10.1007/s00223-013-9777-8

137. Nakamura T, Sugimoto T, Nakano T, Kishimoto H, Ito M, Fukunaga M, et al. Randomized teriparatide [human parathyroid hormone (PTH) 1-34] onceweekly efficacy research (TOWER) trial for examining the reduction in new vertebral fractures in subjects with primary osteoporosis and high fracture risk. J Clin Endocrinol Metab. (2012) 97:3097-106. doi: 10.1210/jc.2011-3479

138. Neer RM, Arnaud CD, Zanchetta JR, Prince R, Gaich GA, Reginster J-Y, et al. Effect of parathyroid hormone (1-34) on fractures and bone mineral density in postmenopausal women with osteoporosis. N Engl J Med. (2001) 344:1434-41. doi: 10.1056/NEJM200105103441904

139. Greenspan SL, Bone HG, Ettinger MP, Hanley DA, Lindsay R, Zanchetta JR, et al. Effect of recombinant human parathyroid hormone (1-84) on vertebral fracture and bone mineral density in postmenopausal women with osteoporosis. A randomized trial. Ann Intern Med. (2007) 146:32639. doi: 10.7326/0003-4819-146-5-200703060-00005

140. Liu Y, Cao Y, Zhang S, Zhang W, Zhang B, Tang Q, et al. Romosozumab treatment in postmenopausal women with osteoporosis: a meta-analysis of randomized controlled trials. Climacteric. (2018) 21:189-95. doi: 10.1080/13697137.2018.1433655

141. Roux C, Briot K. The crisis of inadequate treatment in osteoporosis. Lancet Rhumatol. (2020) 2:110-9. doi: 10.1016/S2665-9913(19)30136-5

142. Arrowsmith J, Miller P. Trial watch: phase II and phase III attrition rates 2011-2012. Nat Rev Drug Discov. (2013) 12:569. doi: 10.1038/nrd4090

143. Harrison RK. Phase II and phase III failures: 2013-2015. Nat Rev Drug Discov. (2016) 15:817-18. doi: 10.1038/nrd.2016.184

144. Nelson MR, Tipney H, Painter JL, Shen J, Nicoletti P, Shen Y, et al. The support of human genetic evidence for approved drug indications. Nat Genet. (2015) 47:856-60. doi: 10.1038/ng.3314

145. King EA, Wade Davis J, Degner JF. Are drug targets with genetic support twice as likely to be approved? Revised estimates of the impact of genetic support for drug mechanisms on the probability of drug approval. PLoS Genet. (2019) 15:e1008489. doi: 10.1371/journal.pgen.1008489

146. Kathiresan S, Melander O, Guiducci C, Surti A, Burtt NP, Rieder MJ, et al. Six new loci associated with blood low-density lipoprotein cholesterol, highdensity lipoprotein cholesterol or triglycerides in humans. Nat Genet. (2008) 40:189-97. doi: 10.1038/ng.75

147. Okada Y. From the era of genome analysis to the era of genomic drug discovery: a pioneering example of rheumatoid arthritis. Clin Genet. (2014) 86:432-40. doi: 10.1111/cge.12465

148. Finan C, Gaulton A, Kruger FA, Lumbers RT, Shah T, Engmann J, et al. The druggable genome and support for target identification and validation in drug development. Sci Transl Med. (2017) 9:eaag1166. doi: 10.1126/scitranslmed.aag1166

149. Chesmore K, Bartlett J, Williams SM. The ubiquity of pleiotropy in human disease. Hum Genet. (2018) 137:39-44. doi: 10.1007/s00439-017-1854-z

150. Sriram K, Insel PA. G protein-coupled receptors as targets for approved drugs: How many targets and how many drugs? Mol Pharmacol. (2018) 93:251-8. doi: 10.1124/mol.117.111062 
151. Wright CL, Mist SD, Ross RL, Jones KD. Duloxetine for the treatment of fibromyalgia. Expert Rev Clin Immunol. (2010) 6:745-56. doi: 10.1586/eci.10.64

152. Brown JP, Boulay LJ. Clinical experience with duloxetine in the management of chronic musculoskeletal pain. A focus on osteoarthritis of the knee. Ther Adv Musculoskelet Dis. (2013) 5:291-304. doi: 10.1177/1759720X13508508

153. Wernicke JF, Pritchett YL, D'Souza DN, Waninger A, Tran P, Iyengar S, et al. A randomized controlled trial of duloxetine in diabetic peripheral neuropathic pain. Neurology. (2006) 67:1411-20. doi: 10.1212/01.wnl.0000240225.04000.1a

154. van der Heijden L, Dijkstra PDS, Blay JY, Gelderblom H. Giant cell tumour of bone in the denosumab era. Eur J Cancer. (2017) 77:7583. doi: 10.1016/j.ejca.2017.02.021

155. Roux S, Mariette X. RANK and RANKL expression in giant-cell tumour of bone. Lancet Oncol. (2010) 11:514. doi: 10.1016/S1470-2045(10)70076-0

156. Anderson DM, Maraskovsky E, Billingsley WL, Dougall WC, Tometsko ME, Roux ER, et al. A homologue of the TNF receptor and its ligand enhance T-cell growth and dendritic-cell function. Nature. (1997) 390:1759. doi: $10.1038 / 36593$

157. Kong YY, Yoshida H, Sarosi I, Tan HL, Timms E, Capparelli C, et al. OPGL is a key regulator of osteoclastogenesis, lymphocyte development and lymph-node organogenesis. Nature. (1999) 397:315-23. doi: 10.1038/16852

158. Angela Y, Haferkamp S, Weishaupt C, Ugurel S, Becker JC, Oberndörfer F, et al. Combination of denosumab and immune checkpoint inhibition: experience in 29 patients with metastatic melanoma and bone metastases. Cancer Immunol Immunother. (2019) 68:1187-94. doi: 10.1007/s00262-019-02353-5

159. Afzal MZ, Shirai K. Immune checkpoint inhibitor (anti-CTLA-4, anti-PD1) therapy alone versus immune checkpoint inhibitor (anti-CTLA-4, antiPD-1) therapy in combination with anti-RANKL denosumuab in malignant melanoma: a retrospective analysis at a tertiary care center. Melanoma Res. (2018) 28:341-7. doi: 10.1097/CMR.0000000000000459

160. Coleman R, Gray R, Powles T, Paterson A, Gnant M, Bergh J, et al. Adjuvant bisphosphonate treatment in early breast cancer: meta-analyses of individual patient data from randomised trials. Lancet. (2015) 386:135361. doi: 10.1016/S0140-6736(15)60908-4

161. Hue TF, Cummings SR, Cauley JA, Bauer DC, Ensrud KE, Barrett-Connor E, et al. Effect of bisphosphonate use on risk of postmenopausal breast cancer: results from the randomized clinical trials of alendronate and zoledronic acid. JAMA Intern Med. (2014) 174:1550-57. doi: 10.1001/jamainternmed.2014.3634

162. Kobayashi Y, Kashima H, Rahmanto YS, Banno K, Yu Y, Matoba $\mathrm{Y}$, et al. Drug repositioning of mevalonate pathway inhibitors as antitumor agents for ovarian cancer. Oncotarget. (2017) 8:72147-56. doi: 10.18632/oncotarget.20046

163. Green JR. Antitumor effects of bisphosphonates. Cancer. (2003) 97:84047. doi: $10.1002 / \mathrm{cncr} .11128$

164. Kranenburg G, Bartstra JW, Weijmans M, de Jong PA, Mali WP, Verhaar HJ, et al. Bisphosphonates for cardiovascular risk reduction: a systematic review and meta-analysis. Atherosclerosis. (2016) 252:10615. doi: 10.1016/j.atherosclerosis.2016.06.039

165. Paananen J, Fortino V. An omics perspective on drug target discovery platforms. Brief Bioinform. (2019) doi: 10.1093/bib/bbz122. [Epub ahead of print].

166. Fotis C, Antoranz A, Hatziavramidis D, Sakellaropoulos T, Alexopoulos LG. Network-based technologies for early drug discovery. Drug Discov Today. (2018) 23:626-35. doi: 10.1016/j.drudis.2017.12.001

167. Ozdemir ES, Halakou F, Nussinov R, Gursoy A, Keskin O. Methods for discovering and targeting druggable protein-protein interfaces and their application to repurposing. Methods Mol Biol. (2019) 1903:121. doi: 10.1007/978-1-4939-8955-3_1

168. Xue H, Li J, Xie H, Wang Y. Review of drug repositioning approaches and resources. Int J Biol Sci. (2018) 14:1232-44. doi: 10.7150/ijbs.24612

169. Walker VM, Davies NM, Hemani G, Zheng J, Haycock PC, Gaunt $\mathrm{TR}$, et al. Using the MR-Base platform to investigate risk factors and drug targets for thousands of phenotypes. Wellcome Open Res. (2019) 4:113. doi: 10.12688/wellcomeopenres.15334.2
170. Walker VM, Davey Smith G, Davies NM, Martin RM. Mendelian randomization: a novel approach for the prediction of adverse drug events and drug repurposing opportunities. Int J Epidemiol. (2017) 46:207889. doi: 10.1093/ije/dyx207

171. Sanseau P, Agarwal P, Barnes MR, Pastinen T, Brent Richards J, Cardon LR, et al. Use of genome-wide association studies for drug repositioning. Nat Biotechnol. (2012) 30:317-20. doi: 10.1038/nbt.2151

172. Wang ZY, Zhang HY. Rational drug repositioning by medical genetics. Nat Biotechnol. (2013) 31:1080-82. doi: 10.1038/nbt.2758

173. Schmidt AF, Finan C, Gordillo-Marañón M, Asselbergs FW, Freitag F, Patel $\mathrm{RS}$, et al. Genetic drug target validation using mendelian randomization. Nat Commun. 11:3255. doi: 10.1038/s41467-020-16969-0

174. Zheng J, Haberland V, Baird D, Walker V, Haycock PC, Hurle MR, et al. Phenome-wide Mendelian randomization mapping the influence of the plasma proteome on complex diseases. Nat Genet. (2020) 2020:1-10. doi: 10.1038/s41588-020-0682-6

175. Sabatine MS, Giugliano RP, Wiviott SD, Raal FJ, Blom DJ, Robinson J, et al. Efficacy and safety of evolocumab in reducing lipids and cardiovascular events. N Engl J Med. (2015) 372:1500-9. doi: 10.1056/NEJMoa1500858

176. Ference BA, Robinson JG, Brook RD, Catapano AL, Chapman MJ, Neff DR, et al. Variation in PCSK9 and HMGCR and risk of cardiovascular disease and diabetes. N Engl J Med. (2016) 375:2144-53. doi: 10.1056/NEJMoa1604304

177. Schmidt AF, Swerdlow DI, Holmes MV, Patel RS, Fairhurst-Hunter Z, Lyall DM, et al. PCSK9 genetic variants and risk of type 2 diabetes: a mendelian randomisation study. Lancet Diabetes Endocrinol. (2017) 5:97105. doi: 10.1016/S2213-8587(16)30396-5

178. Lin TK, Chou P, Lin CH, Hung YJ, Jong GP. Long-term effect of statins on the risk of new-onset osteoporosis: a nationwide population-based cohort study. PLoS ONE. (2018) 13:e0196713. doi: 10.1371/journal.pone.0196713

179. Scranton RE, Young M, Lawler E, Solomon D, Gagnon D, Gaziano JM. Statin use and fracture risk: study of a US veterans population. Arch Intern Med. (2005) 165:2007-2012. doi: 10.1001/archinte.165.17.2007

180. Li GH-Y, Cheung C-L, Au PC-M, Tan KC-B, Wong IC-K, Sham P-C. Positive effects of low LDL-C and statins on bone mineral density: an integrated epidemiological observation analysis and mendelian randomization study. Int J Epidemiol. (2019) 13:dyz145. doi: 10.1093/ije/dyz145

181. Zheng J, Brion M, Kemp JP, Warrington NM, Borges M, Hemani G, et al. The effect of plasma lipids and lipid-lowering interventions on bone mineral density: a mendelian randomization study. J Bone Miner Res. (2020) 35:1224-35. doi: 10.1002/jbmr.3989

182. Urnov FD, Rebar EJ, Holmes MC, Zhang HS, Gregory PD. Genome editing with engineered zinc finger nucleases. Nat Rev Genet. (2010) 11:63646. doi: $10.1038 / \operatorname{nrg} 2842$

183. Boch J, Scholze H, Schornack S, Landgraf A, Hahn S, Kay S, et al. Breaking the code of DNA binding specificity of TAL-type III effectors. Science. (2009) 326:1509-12. doi: 10.1126/science.1178811

184. Al-Attar S, Westra ER, Van Der Oost J, Brouns SJJ. Clustered regularly interspaced short palindromic repeats (CRISPRs): the hallmark of an ingenious antiviral defense mechanism in prokaryotes. Biol Chem. (2011) 392:277-89. doi: 10.1515/bc.2011.042

185. Gaj T, Gersbach CA, Barbas CF. ZFN, TALEN, and CRISPR/Cas-based methods for genome engineering. Trends Biotechnol. (2013) 31:397405. doi: 10.1016/j.tibtech.2013.04.004

186. Li H, Yang Y, Hong W, Huang M, Wu M, Zhao X. Applications of genome editing technology in the targeted therapy of human diseases: mechanisms, advances and prospects. Signal Transduct Target Ther. (2020) 5:1-23. doi: 10.1038/s41392-019-0089-y

187. Maynard RD, Ackert-Bicknell CL. Mouse models and online resources for functional analysis of osteoporosis genome-wide association studies. Front Endocrinol. (2019) 10:277. doi: 10.3389/fendo.2019.00277

188. Bergen DJM, Kague E, Hammond CL. Zebrafish as an emerging model for osteoporosis: a primary testing platform for screening new osteo-active compounds. Front Endocrinol. (2019) 10:6. doi: 10.3389/fendo.2019.00006

189. Wu N, Liu B, Du H, Zhao S, Li Y, Cheng X, et al. The progress of CRISPR/Cas9-mediated gene editing in generating mouse/zebrafish models of human skeletal diseases. Comput Struct Biotechnol J. (2019) 17:95462. doi: 10.1016/j.csbj.2019.06.006 
190. Rauch F, Geng Y, Lamplugh L, Hekmatnejad B, Gaumond MH, Penney J, et al. Crispr-Cas9 engineered osteogenesis imperfecta type $\mathrm{V}$ leads to severe skeletal deformities and perinatal lethality in mice. Bone. (2018) 107:131-42. doi: 10.1016/j.bone.2017.11.013

191. Canalis E, Yu J, Schilling L, Yee SP, Zanotti S. The lateral meningocele syndrome mutation causes marked osteopenia in mice. J Biol Chem. (2018) 293:14165-77. doi: 10.1074/jbc.RA118.004242

192. Mochizuki Y, Chiba T, Kataoka K, Yamashita S, Sato T, Kato T, et al. Combinatorial CRISPR/Cas9 approach to elucidate a far-upstream enhancer complex for tissue-specific Sox9 expression. Dev Cell. (2018) 46:794806.e6. doi: 10.1016/j.devcel.2018.07.024

193. Cho TJ, Lee KE, Lee SK, Song SJ, Kim KJ, Jeon D, et al. A single recurrent mutation in the $5^{\prime}$-UTR of IFITM 5 causes osteogenesis imperfecta type v. Am J Hum Genet. (2012) 91:343-8. doi: 10.1016/j.ajhg.2012. 06.005

194. Duan X, Liu J, Zheng X, Wang Z, Zhang Y, Hao Y, et al. Deficiency of ATP6V1H causes bone loss by inhibiting bone resorption and bone formation through the TGF- $\beta 1$ pathway. Theranostics. (2016) 6:218395. doi: 10.7150/thno.17140
195. Zhang Y, Huang H, Zhao G, Yokoyama T, Vega H, Huang $\mathrm{Y}$, et al. ATP6V1H deficiency impairs bone development through activation of MMP9 and MMP13. PLoS Genet. (2017) 13:e1006624. doi: 10.1371/journal.pgen.1006624

196. Shapiro G, Lieber R, Gazit D, Pelled G. Recent advances and future of gene therapy for bone regeneration. Curr Osteoporos Rep. (2018) 16:504-11. doi: $10.1007 /$ s11914-018-0459-3

Conflict of Interest: The authors declare that the research was conducted in the absence of any commercial or financial relationships that could be construed as a potential conflict of interest.

Copyright (c) 2020 Trajanoska and Rivadeneira. This is an open-access article distributed under the terms of the Creative Commons Attribution License (CC BY). The use, distribution or reproduction in other forums is permitted, provided the original author(s) and the copyright owner(s) are credited and that the original publication in this journal is cited, in accordance with accepted academic practice. No use, distribution or reproduction is permitted which does not comply with these terms. 